Portland State University

PDXScholar

7-7-1995

\title{
Independent Acoustic Stimulation of the Amphibian and Basilar Papillae of Rana pipiens
}

Mark Parker

Portland State University

Follow this and additional works at: https://pdxscholar.library.pdx.edu/open_access_etds

Part of the Speech and Rhetorical Studies Commons

Let us know how access to this document benefits you.

\section{Recommended Citation}

Parker, Mark, "Independent Acoustic Stimulation of the Amphibian and Basilar Papillae of Rana pipiens" (1995). Dissertations and Theses. Paper 4956.

https://doi.org/10.15760/etd.6832

This Thesis is brought to you for free and open access. It has been accepted for inclusion in Dissertations and Theses by an authorized administrator of PDXScholar. Please contact us if we can make this document more accessible: pdxscholar@pdx.edu. 


\section{THESIS APPROVAL}

The abstract and thesis of Mark Parker for the Master of Science in Speech

Communication: Speech and Hearing Sciences were presented July 7, 1995, and accepted by the thesis committee and the department.

COMMTTTEE APPROVALS:

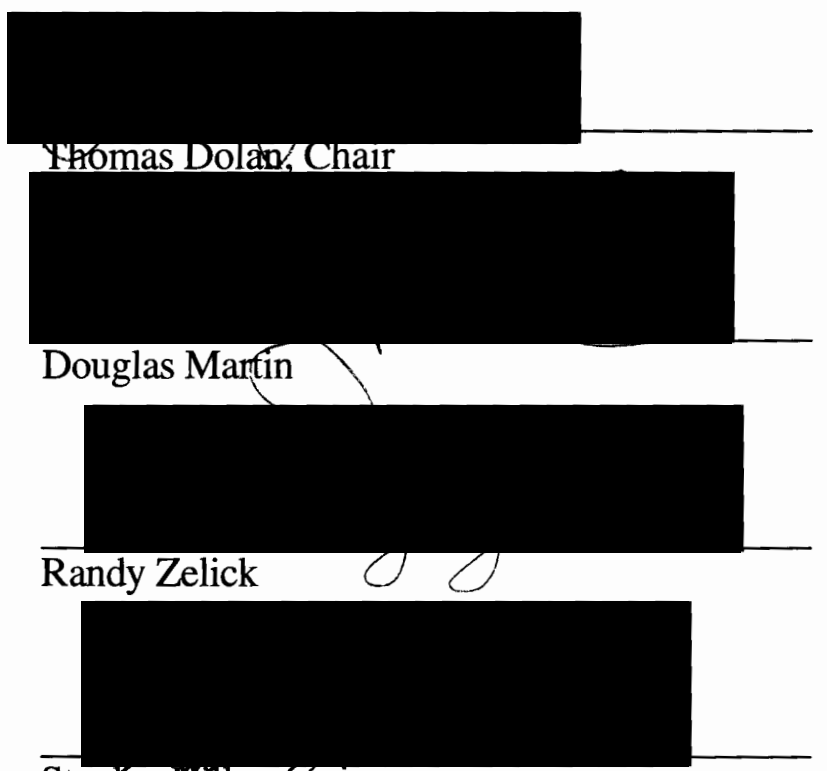

Staniey Hillmar

Representative of the Office of Graduate Studies

DEPARTMENT APPROVAL:

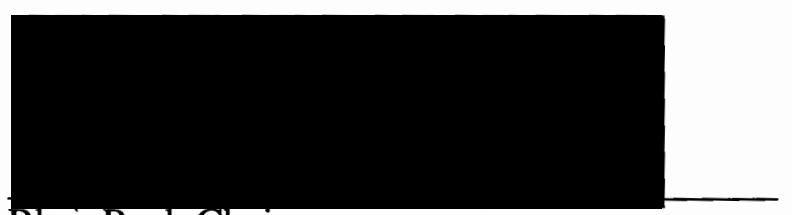

Rhea Paul, Chair

Department of Speech Communication

$* * * * * * * * * * * * * * * * * * * * * * * * * * * * * * * * * * * * * * * * * * * * * *$

ACCEPTED FOR PORTLAND STATE UNIVERSITY BY THE LIBRARY

by

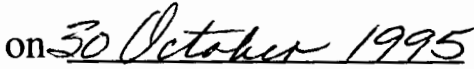




\begin{abstract}
An abstract of the thesis of Mark Parker for the Master of Science Degree in Speech Communication: Speech and Hearing Science presented July 7, 1995.

Title: Independent Acoustic Stimulation of the Amphibian and Basilar Papillae of Rana pipiens

This study attempted to selectively stimulate and record from either the amphibian or basilar papillae of Rana pipiens. Computer-generated, frequency-specific clicks were used to elicit BSER's from either amphibian or basilar papillae. Narrowband noise fatiguers were presented in the frequency region of which each papillae are tuned. It was expected that a threshold shift would be elicited in the papillae that received the acoustic trauma, and that no threshold shift would be observed from the collateral papilla.
\end{abstract}

The results of this experiment indicated that there was no overall difference between the threshold shift of either papilla. Furthermore, the amount of AP threshold shift was relatively constant regardless of whether the fatiguer bandwidth was overloading the amphibian or basilar papillae. By contrast, the amount of BP threshold shift was greater when proceeded by a fatiguer with a bandwidth corresponding to the BP tuning region than by a fatiguer with a bandwidth corresponding to the AP tuning region. Additionally, curare maximized the amount of BP threshold shift following fatiguing noise presented with a bandwidth to which the $\mathrm{AP}$ is tuned. 
BASILAR PAPILLAE OF RANA PIPIENS

by

Mark Parker

A thesis submitted in partial fulfillment of the requirements for the degree of

\author{
MASTER OF SCIENCE \\ in \\ SPEECH COMMUNICATION: \\ SPEECH AND HEARING SCIENCES
}

Portland State University

1995 


\section{INTRODUCTION}

We are living in a society that is increasingly becoming satiated with noise. Although humans have been on this earth for over a million and a half years, the basic structure of the auditory system that we share with other mammals has been evolving for over 248 million years. As humans, our auditory system has selectively evolved both morphologically and physiologically to accommodate our adaptive needs, which were primarily defense and social communication.

The dawn of the Industrial Revolution has introduced a new strain on our auditory system. Manufacturing plants, power-tools, fire arms, automobiles, and rock concerts are a few examples of the noisy environment that modern man inhabits. Our auditory system suffers accordingly as evident in the Noise Induced Permanent Threshold Shift (NIPTS) routinely measured and treated by audiologists. The high incidence of NIPTS has directed efforts to reduce the maleffects that environmental noise has on the auditory system.

It is well documented that in guinea pigs, pre-exposure to certain low level stimuli results in a reduction in elevation of brainstem auditory evoked responses (BAER) thresholds caused by exposure to intense stimuli (Hirsch, 1958; Cody, \& Johnstone, 1982; Rajan, \& Johnstone, 1988; Patuzzi, \& Thompson, 1991). This "acoustic toughening" effect has been observed with ipsilateral (Cody, \& Johnstone, 1981; Rajan, \& Johnstone, 1983a), contralateral (Rajan, \& Johnstone, 1983b), or binaural (Canlon, Borg, \& Flock, 1988) introduction of a low intensity pure tone prior to 
exposure of a pure tone at intensities known to cause threshold shift.

The acoustic toughening effect may be a means of NIPTS protection because it appears to utilize a naturally occurring mechanism. Evidence suggests that the efferent system may be involved in the protection of the mechano-electrical transduction mechanism of the outer hair cells (Canlon, Borg, Flock, 1988; Rajan, \& Johnstone, 1983a, 1983b, 1988; Patuzzi, \& Thompson, 1991). Electrical stimulation of the efferent system has been shown to cause significant changes in acoustic toughening. It is documented that an efferent fiber tract innervates both cochleas via the olivo-cochlear pathway (Art et al., 1984; Brownell et al., 1985; Wersall, et al., 1965) and effectively acts as a communication link between the two cochleas. Simultaneous electrical stimulation of the efferent system at the level of crossed olivocochlear bundle and exposure to a threshold shifting noise has been shown to reduce the expected amount of threshold shift (Rajan. 1988a, 1988b). The reduction is highly correlated with reduction in threshold shifts due to acoustic pre-exposure (Rajan, \& Johnstone, 1988). Known efferent inhibitors appear to reverse the electrically stimulated protective effect of pre-exposure to low level pure tones (Sigel \& Kim, 1982; Rajan \& Johnstone, 1983; Rajan, 1988a; Rajan, \& Johnstone. 1988a; Rajan, 1990; Corwin \& Warchol, 1991; Boettcher, et al., 1992). Additionally, ablation of the contralateral cochlea (Rajan, \& Johnstone, 1983b) and transection of the efferent pathway has been shown to reverse the threshold protective effect provided by acoustic stimulation (Rajan, \& Johnstone, 1988, 1989; Patuzzi, \& Thompson, 1991).

Based on the observations that acoustic pre-stimulation mimics results obtained 
from electrical stimulation of the efferent system, it has been proposed that the acoustic stimuli used in these experiments somehow stimulates the efferent system. The efferent system is thus believed to be part of an unidentified cochlear protective mechanism (Canlon, Borg, \& Flock, 1988; Patuzzi, \& Thompson, 1991). However, the results of some experiments on efferent system involvement in response to acoustic stimuli are inconclusive. Specifically, there has been conflicting evidence as to whether efferent antagonists effectively reverse the protective effect elicited by acoustic stimuli. Rajan \& Johnstone (1983b) observed that strychnine, a known efferent antagonist, reversed the threshold shift protection caused by contralateral cochlear ablation. However, Rajan \& Johnstone (1983a) observed that strychnine had no effect on acoustic toughening. It has been left to be determined, possibly via a more appropriate animal model, as to the extent of efferent involvement in response to acoustic stimuli.

Anurans (frogs and toads) are a valid model in experiments on efferent involvement in acoustic toughening. They possess many fundamental features of audition common to all terrestrial mammals (Wilczinski \& Capranica, 1983). In addition, anurans possess two auditory sensory epithelia in each inner ear, the amphibian papilla (AP) and basilar papilla (BP). The AP is more complex than the BP, and is similar to the mammalian cochlea in that it supports a traveling wave (Hillery \& Narins, 1984), is tonotopically organized (Lewis, Leverenz, \& Koyama, 1982), and contains efferent innervation (Capranica, 1976; Wilczinski \& Capranica, 1983). Although it contains afferent projections, the BP lacks efferent projections, shows no apparent tonotocicity, and does not appear to support a traveling wave (Capranica, 1976; Capranica, 1983; 
Wilczinski \& Capranica, 1983; Ronken, 1990).

Another distinction between the two papilla is the frequency range to which they respond. Single unit measurements indicate that the two papillae respond to separate frequency regions, and that the AP responds to lower frequencies than the BP (Feng, Narins, \& Capranica, 1975; Simmons, Bertolotto, \& Narins, 1992). The fact that anurans are equipped with two auditory sensory organs that are each tuned to different frequency bandwidths proposes that the selective stimulation of only one of the two papilla is possible.

Single unit tuning curves in the leopard frog Rana pipiens have demonstrated that the AP responds to frequencies ranging from $100-1100 \mathrm{~Hz}$, and the $\mathrm{BP}$ responds to the 1100-2300 Hz bandwidth (Megela, \& Capranica, 1981; Ronken, 1990). Theoretically, a stimulus may be developed that would elicit a response from either organ independently of the other. For instance, a $1600 \mathrm{~Hz}$ sinusoid should elicit a response from the BP and not the AP because the AP does not have neural fibers tuned to this frequency region. Therefore, it may be possible to selectively stimulate and record brainstem evoked responces (BSER's) from one papilla independently from the other based on the frequency parameters of the stimuli. Selective stimulation of either papillae may enable experimental investigation of physiological differences between the relatively "simple" basilar papilla and the more complex, mammalian-like amphibian papilla. Such an investigation may illuminate organ-specific BESR response differences of the acoustic toughening effect, efferent innervation, or differences in tonotopic organization of the two papillae. 
It is the purpose of this study to determine if the amphibian and basilar papillae can be independently fatigued using narrow band noise. Narrow band noise may be applied to fatigue one organ independently of the other based on the bandwidth of the noise. If the fatiguer affects only one of the two papillae, it would be expected that threshold recovery could be measured from the papilla subject to fatigue while no threshold shift should be observed from the colateral papilla.

Computer-generated, frequency specific clicks will be used to elicit BESR evoked responses from either papillae. A click with the bandwidth of $150-1100 \mathrm{~Hz}$ will be used to determine threshold in the amphibian papilla, and a click with the bandwidth of $1600-2500 \mathrm{~Hz}$ will be used to determine threshold in the basilar papilla. A computer generated narrow band $103 \mathrm{~dB}$ SPL noise will be used to fatigue a particular organ, and threshold recovery will be measured from each papilla using the computer generated clicks. Three narrow band fatiguing noises will be used with upper and lower cut-offs of $150-600 \mathrm{~Hz}$ and $150-1100 \mathrm{~Hz}$ to fatigue the amphibian papilla, and a $1100-3000 \mathrm{~Hz}$ noise to fatigue the basilar papilla.

It is expected that the BP fatiguing noise will cause the BP thresholds to shift without a corresponding shift in AP thresholds. Likewise, the AP fatiguing noise is expected to shift the AP thresholds independently from thresholds recorded from the BP. It will be assumed that organ-specific adaption has not occurred if the BP fatiguing noise causes the AP thresholds to shift and the AP fatiguing noise causes the BP thresholds to shift. 


\section{LITERATURE REVIEW}

\section{Quter and Inner Ear Morphology and Function}

All anuran species lack a pinna and external ear canal. In most species, a relatively large tympanum is located caudal to the eyes and serves as a boarder membrane between the environment and the middle ear space. A few species of anurans lack a tympanum (Capranica, 1976; 1977; Wilczynski\& Capranica 1983). The air filled middle ear space is relatively large and contains an ossicular complex and a relatively large eustachian tube that is always open (Narins, et al., 1988).

Most anurans possess an ossicular complex analogous to mammals, consisting of three middle ear bones that transduce acoustical sound energy of the environment to mechanical-fluid energy in the internal ear (Weaver, 1979). An extracolumellar bone is directly connected to the middle of the tympanum by a ligament. a stiff joint connects the extracolumella to the columella proper. The columella contains a footplate that covers a portion of the oval window of the inner ear. The rest of the oval window is covered by the operculum which forms a complex joint with the columella. Therefore, the operculum and the columella act together to transfer mechanical energy to inner ear. Weaver (1979) describes the presence of two middle ear smooth muscles in anurans with opposing functions. The opercularis muscle attaches to the operculum and acts to pull it from the oval window. The columellar muscle attaches to the columellar footplate itself. Contraction of the two muscles pulls the two bones together, locking them (Hetherington, et al., 1986). Wilczynski \& Capranica (1983) say that these muscles act to 
control the overall gain of the middle ear, and that they may serve a protection function to high intensity stimuli. These muscles may be considered functionally equivalent to the tensor tympani and stapedius muscles of mammals.

The energy transfer of the operculum and columellar complex is slightly less

efficient than in mammals (Capranica, 1977; Wilczynski, \& Capranica 1984). Moffat \& Capranica (1978) described the middle ear impedance matching characteristics in Bufo americanus. They estimate that the shape of the tympanum provides a 1.7 magnitude increase in power delivered to the ossicular complex, and additionally, the ossicular complex provides a lever ratio of 5:1. Finally, the area-ratio difference between the tympanum and the oval window accounts for a 10.3 pressure increase at the oval window. These authors found that the overall transfer ratio in Bufo americanus has a 60 magnitude increase, which approximates the 63 magnitude impedance mismatch of sound energy transduction top the anuran inner ear.

\section{Inner Ear Morphology and Function}

The fluid systems of the anuran inner ear consist of a perilymphatic system and endolymphatic system. The perilymphatic system is a series of fluid filled spaces between the bony labyrinth and the membranous labyrinth. The perilymphatic cistern receives ossicular vibration and is connected to the perilymphatic sac by the perilymphatic duct. The perilymphatic sac serves a pressure/release function, bulging into the cerebral-spinal fluid environment of the brain case.

The endolymphatic system consists of a series of membrane bound channels and 
reservoirs called diverticulum. The sensory cells of the inner ear are each located in their respected endolymph filled diverticulum, and are separated from the perilymph by a thin contact membrane. The anuran inner ear consists of eight sensory organs each with a distinct set of sensory cells (Wilczynski \& Capranica, 1983; Simmons, Bertolotto, \& Narins 1992). The three semicircular canals, utricle, saccule and lagena function in vestibular integration, although there is evidence that the saccule may respond to low frequency sounds and seismic vibration below $100 \mathrm{~Hz}$ (Capranica 1976; Caston \& Gribenski 1979; Wilczynski \& Capranica, 1983; Yu, Lewis, \& Field, 1990).

The remaining two sensory organs, the amphibian papilla and basilar papilla, respond only to acoustic stimuli. All anurans have two auditory sensory organs each responding to separate frequency bands, and each housed in their respective diverticula. Neither papilla has sensory cells resting on a moveable basilar membrane.

\section{Amphibian Papilla Morphology}

The amphibian papilla (AP) is larger than the basilar papilla (BP), and responds to low frequency acoustic stimuli. The AP is composed of supporting cells and hair cells firmly attached to the anterior wall of the AP diverticulum, rather than to a moveable basilar membrane. Lewis (1982) describes the AP as a chamber bound by the thick labyrinth wall. The chamber is closed on the medial side and a thin contact membrane forms a boundary between endolymph and the perilymphatic canal. The perilymphatic canal provides direct fluid coupling to the hair cells from the oval window. The ceiling of the AP chamber forms the floor of the horizontal and posterior semi-circular canals. The 
hair cells are distributed into a long S-shaped tail along the papilla. Each hair cell has a stereocilia bundle and a large kinocillium. The kinocillium orientation varies along the sensory epithelium with some adjacent cells exhibiting opposite kinocillium polarity. The kinocillia have a bulb at their distal end and all kinocillia are attached to the tectum. An acellular tectum hangs from the papilla and has 2 layers; $a$ thin fibrous proximal layer immediately adjacent to the papilla, and a more dense and thicker gelatinous "distal layer invaded by a system of pores and tunnels" which is coupled to the kinocillium of each bundle (Lewis, 1982). The remaining volume of the papilla is filled with endolymph. A thin diaphragm-like tectorial projection extends from the ceiling to the floor and from wall to wall of the AP chamber. This appears to be directly in the path that would induce acoustical signals.

The adult bullfrog AP is innervated by about 1,500 myelinated axons from the posterior branch of the VIII ${ }^{\text {th }}$ cranial nerve (Wilczynski \& Capranica, 1983). Each axon innervates from 1 to 15 different hair cells (Lewis, et, al., 1982). Efferent projections are present in the AP and are more frequent in the rostral hair cells. AP hair cells are finely tuned with charicteristic frequencys ranging from less than $100 \mathrm{~Hz}$ to about $1300 \mathrm{~Hz}$ depending on the species. Two tone suppression (Feng Narins, \& Capranica, 1977), cubic difference tone and simple difference tone distortion products have also been recorded in the AP (Wilczynski \& Capranica, 1983). Schmitz, et al., (1992) observed that AP neurons exhibit significant phase locking to short tone bursts at the charicteristic frequency, but BP fibers do not. Hillery \& Narins (1984) have found evidence that the AP supports a traveling wave. In their view, the tectum may support a traveling wave due 
to its own stiffness gradient caused by the tectum being massive at the rostral end and flaccid at the caudal end. Lewis et al (81) have proposed that this stiffness gradient accounts for the observed AP tonotopy with low frequencies represented at the thicker rostral end and high frequencies represented at the flaccid caudal end closest to the contact membrane.

\section{Basilar Papillla Morphology}

The BP is the smaller of the two auditory organs and is located in a tubular diverticulum off the posterior wall of the saccular chamber. It is formed by a layer of supporting cells topped by several rows of hair cells arranged in a semicircle around the inner wall of the tube (Wilczynski \& Capranica, 1983). The hair cells are fixed to an immoveable substrate, so like the AP, the BP lacks a basilar membrane. A contact membrane forms a boundary between the endolymph and the perilymphatic canal. Depending on the species, there are about 50-95 hair cells in 5-6 rows on the $100 \mathrm{~mm}$ long papilla (Lewis, 1982). Each hair cell has a long Kinocillium located on the side of a bundle of short stereocilium nearest to the contact membrane. In the BP, each kinocillium is oriented in the same direction. A tectum overlies the medial hair cells and the Kinocillium of hair cells are directly attached. The cilia of the lateral hair cell cilia are freestanding in endolymph (Wilczynski \& Capranica, 1983).

BP hair cells are innervated by fibers of the VIII ${ }^{\text {th }}$ cranial nerve's posterior branch (Wilczynski \& Capranica, 1983; Feng, Narins, \& Capranica, 1975). One axon contacts one hair cell, but each hair cell is innervated by many axons (Lewis, et, al., 1982). The 
BP fibers are all tuned to a species-specific narrow or single frequency region, and these fibers are always tuned to frequencies higher than those of the AP, although some crossover has been shown (Feng et al., 1975; Capranica, 1977). No efferent innervation, two-tone suppression, significant phase locking or Distortion products have been observed in the BP (Bricout-Berthout \& Caston, 1982; Hillery \& Narins, 1984; Ronken, 1990; Rossi, et al, 1980; Schmitz, et al, 1992). The fluid path and hair cell displacement in the anuran inner ear is not entirely clear. Weaver (1973) suggests that:

"Pressure vibrations induced in the cistern by the ossicular motion pass directly into the endolymphatic fluid space of the sacculus through the thin membranous wall of the labyrinth and from there are channeled through the tubular diverticula housing the papilla and out into the perilymphatic sac through the contact membrane. Since the diverticula are partially blocked by the tectorial membranes over both papilla, the fluid displacement will tug on these structures thereby activating cells by a shearing motion."

\section{Amphibian and Basilar Papillae Tuning}

Feng, Narins, \& Capranica (1975) were the first to definitively track the origins of the low and high frequency fibers in the bullfrog Rana catesbeiana $(\mathrm{N}=12)$. Feng et al. described three populations of VIIIth nerve fibers characterized by their BEF and whether or not the units were inhibitable. Recording from the trunk of the VIIIth nerve, a low frequency fiber population with BEFs ranging from $0-600 \mathrm{~Hz}$ were shown to be subject to $300-600 \mathrm{~Hz}$ tone-on-tone inhibition. However, neither a mid frequency population (BEF's of 450-900 Hz) nor a high frequency fiber population (BEF's of 1000- 
$1700 \mathrm{~Hz}$ ) were subject to tone-on-tone inhibition.

In one animal, the anterior portion of the VIIIth nerve was lesioned, effectively eliminating possible responses from the saccule, utricle, horizontal semicircular canal, and anterior ventral semicircular canal. Recordings from the intact posterior portion of the VIIIth nerve exhibited the presence of all three populations, indicating that these originate from either the lagena, AP, BP, or posterior ventral semicircular canal. Similarly, when the neural branches originating from the lagena and the posterior ventral semicircular canal were sectioned in other animals, similar fiber populations were encountered. Finally, Feng et al. (1975) found that when the neural branch leading to the BP was severed, only the inhibitable low frequency fibers and the non-inhibitable mid frequency fibers were present. Comparably, when the neural branch originating from the AP was severed, only the high frequency non-inhibitable fibers were encountered. Feng et al. (1975) deduced that the posterior portion of the VIIIth nerve was arranged tonotopically with the most ventral high frequency fibers originating from the $\mathrm{BP}$, and the most dorsal low to mid frequency fibers originating from the AP.

The work of Feng, Narins, \& Capranica was supported by Lewis et al. (1982). The dye Lucifer yellow was injected into individual afferent VIIIth nerve fibers of Rana catesbeiana after auditory fiber BEF's recording. This technique enabled the authors to view the origin of the dye-filled axon under a fluorescent microscope after fixation. They confirmed that high frequency fibers $(\mathrm{BEF}$ of $1000-2000 \mathrm{~Hz}$ ) originate in the BP, and low frequency fibers $(100-1000 \mathrm{~Hz})$ originate in the AP and the saccule. Of the latter low frequency fibers, a majority of those tuned to frequencies below $300 \mathrm{~Hz}$ were 
found to originate within the saccule, and a minority of those tuned from $100-300 \mathrm{~Hz}$ were found to have originated in the AP. Additionally, Lewis, they found that the AP was tonotopically arranged so that those fibers tuned from $100-300 \mathrm{~Hz}$ were located at the rostral end of the papilla, those tuned from $300-600 \mathrm{~Hz}$ were located in the middle portion, and those tuned from $6000-1000 \mathrm{~Hz}$ were located at the caudal end of the papilla.

\section{Inter/Intra-Species Variation of Amphibian and Basilar Papilla Tuning}

Capranica (1977) investigated single unit tuning variation between Rana catesbeiana, Acris crepitans, and Eleutherodactylus coqui. By comparison of BEF's obtained from the VIIIth nerves of these three genera, Capranica identified some speciesspecific observations of papillae tuning. AP BEF's exhibited wide ranges that are consistent within the same species. These species-specific variations presenting BEF tuning range differences only between genera. Additionally, AP fibers were more sensitive than BP fibers. BP BEF variations, however, tend to be clustered within a small band of frequencies. Although the tuning of BP fibers is also species-specific, Capranica (1977) demonstrated that inter-specific BP BEF variation is common.

For example, Capranica et al. (1973) selected samples from two populations of A. crepitans to study inter-specific tuning variations. One sample was collected in South Dakota, and the other from New Jersey. Single unit data collected from the two samples revealed that low frequency cells, presumably originating from the AP, consisted of BEF's distributed over the range of $200-1000 \mathrm{~Hz}$ at thresholds of $35-60 \mathrm{~dB}$ SPL. The high 
frequency cells, presumably originating from the BP, were less sensitive than the AP fibers with thresholds of 75-85 dB SPL and exhibited narrow tuning. However, the New Jersey sample showed BEF's clustered around $3500 \mathrm{~Hz}$ where as the South Dakota sample exhibiting a cluster around $2900 \mathrm{~Hz}$. Capranica et al. (1977) proposed that "whereas the sensitivity of the amphibian papilla seems to remain constant throughout geographic range, the frequency sensitivity of the basilar papilla varies with geographical origin... and is both species-specific and geographically specific (p.348)". Megela \& Capranica (1981) have described similar results recorded from Rana pipiens.

\section{Amphibian and Basilar Papillae Frequency Response of Rana pipiens}

Similarities to Rana catesbeiana

Tuning curves obtained from Rana pipiens have demonstrated general neurophysioloigal similarities to those recorded from Rana catesbeiana. Rana pipiens single units may be divided into three distinct populations based on BEF and two tone suppression (Mudry, et al., 1977; Megela, \& Capranica, 1981; Feng, \& Shoffner, 1981; Feng, et al., 1991; Schmitz, et al., 1992). Whereas AP fiber BEF's are distributed over a range of low to mid frequencies, all $\mathrm{BP}$ fibers are tuned to the same higher $\mathrm{BEF}$ in the same animal. BP BEF's also appear to vary slightly between individuals of a given population (Megela, \& Capranica, 1981). Additionally, BP fibers exhibit a broad tuning curve while AP tuning curves are comparable to those observed in mammals (Ronken, 1990; Schmitz, et al., 1992).

Simmons et al. (1992) labeled VIIIth nerve afferent ganglionic cell bodies and 
projections with horseradish peroxidase (HRana pipiens) and biocytin in Rana pipiens pipiens. The authors found that Rana pipiens pipiens exhibited similar end organ innervation to that described by Feng et al. (1975) and Lewis et al. (1982) in Rana catesbeiana.

Megela \& Capranica (1981) recorded the firing patterns, BEF's, and PST histograms from 140 single units of twenty Rana pipiens. They confirmed that all BP units from the same animal exhibit the same BEF, but different animals within a population may exhibit slightly different BEF's. The authors concluded that AP fibers exhibit BEF's ranging from $100-1100 \mathrm{~Hz}$ and $\mathrm{BP}$ fibers exhibit BEF's ranging from 1100$1800 \mathrm{~Hz}$ with a cluster of BEF's around $1600 \mathrm{~Hz}$.

Ronken (1990) investigated $126 \mathrm{BP}$ automated tuning curves recorded from the VIIIth nerve of 31 Rana pipiens. The results indicated that each animal possesses BP units with similar tuning curve morphology and that are tuned to the same BEF, but the frequency to which an animal is tuned varies between individuals (Ronken, 1990; Megela \& Capranica, 1981). Ronken found that BP fibers displayed a broad peak and a wide tail spanning from $500-4000 \mathrm{~Hz}$ tail-to-tail.

Differences from Rana catesbeiana

The amphibian and basilar papillae tuning curves of Rana pipiens differ by both neural sensitivity and frequency tuning than those recorded in Rana catesbeiana. AP fibers are more sensitive than BP fibers in Rana catesbeiana. However, Schmitz, et al. (1992) found that basilar papilla neural sensitivity is not significantly different from the sensitivity of amphibian papilla fibers in Rana pipiens. 
Additionally, Rana pipiens AP and BP frequency tuning varies from that observed in Rana catesbeiana acoustic papillae. Table 1. lists tuning curve BEF's obtained from five independent single unit studies of Rana pipiens. All authors except Megela \& Capranica (1981) describe two populations of AP fibers. However, Mudry, et al., (1977) and Feng, et al., (1991) were the only authors that describe low frequency AP fiber populations that exhibit two tone suppression when a higher frequency tone is simultaneously presented. None of the authors repeated the VIIIth nerve end organ innervation study of Feng, Narins, \& Capranica (1975), therefore there is some question as to the exact end organ origin of the single units based solely on BEF.

Mudry, et al., (1977) and Megela, \& Capranica (1981) reference end organ innervation based upon the frequencies observed in Rana catesbeiana by Feng, Narins, \& Capranica (1975). These assumptions may be misleading because there is ample evidence that AP and BP tuning differs between species. Feng, \& Shoffner (1981) and Feng, et al., (1991) describe their rational of amphibian or basilar papillae tuning based solely on high or low frequency BEF populations. Schmitz, et al., (1992) based their end organ innervation on the previously described results from Mudry, et al., (1977), Megela, \& Capranica, (1981), and Feng, et al., (1991). Similarly, Ronken (1990) based BP fiber origin on results from Megela \& Capranica (1981). The end organ innervation assumptions of Schmitz, et al., (1992) and Ronken (1990) are subject to the same limitations as previously described. 
Table 1. Single Unit BEF Data in Rana pipiens

\begin{tabular}{|c|c|c|c|c|}
\hline Authors & $\begin{array}{l}\text { Two Tone } \\
\text { Suppression }\end{array}$ & $\mathrm{AP}$ & $\mathrm{AP}$ & $\mathrm{BP}$ \\
\hline $\begin{array}{l}\text { Mudry } \\
\text { (1977) }\end{array}$ & $<500 \mathrm{~Hz}$ & $\begin{array}{l}200-300 \\
\mathrm{~Hz}\end{array}$ & $\begin{array}{l}600- \\
700 \mathrm{~Hz}\end{array}$ & $\begin{array}{l}1400- \\
1800 \\
\mathrm{~Hz}\end{array}$ \\
\hline $\begin{array}{l}\text { Megela \& } \\
\text { Capranica } \\
\text { (1981) }\end{array}$ & & \multicolumn{2}{|c|}{$100-1100 \mathrm{~Hz}$} & $\begin{array}{l}1100- \\
1800 \\
\mathrm{~Hz}\end{array}$ \\
\hline $\begin{array}{l}\text { Feng \& } \\
\text { Shoffner } \\
(1981)\end{array}$ & & $\begin{array}{l}81-475 \\
\mathrm{~Hz}\end{array}$ & $\begin{array}{l}520- \\
1300 \\
\mathrm{~Hz}\end{array}$ & $\begin{array}{l}1350- \\
2850 \\
\mathrm{~Hz}\end{array}$ \\
\hline $\begin{array}{l}\text { Ronken } \\
\text { (1990) }\end{array}$ & & & & $\begin{array}{l}1500- \\
2300 \\
\mathrm{~Hz}\end{array}$ \\
\hline $\begin{array}{l}\text { Feng, Hall } \\
\& \\
\text { Siddique } \\
(1991) \\
\end{array}$ & lo $f$ & $\begin{array}{l}70-600 \\
\mathrm{~Hz}\end{array}$ & $\begin{array}{l}700- \\
1300 \\
\mathrm{~Hz}\end{array}$ & $\begin{array}{l}1400- \\
2300 \\
\mathrm{~Hz}\end{array}$ \\
\hline $\begin{array}{l}\text { Schmitz, } \\
\text { White, \& } \\
\text { Narins } \\
(1992)\end{array}$ & & $\begin{array}{l}59-500 \\
\mathrm{~Hz}\end{array}$ & $\begin{array}{l}500- \\
1254 \\
\mathrm{~Hz}\end{array}$ & $\begin{array}{l}1254- \\
2700 \\
\mathrm{~Hz}\end{array}$ \\
\hline
\end{tabular}

evidence that AP and BP tuning differs between species. Feng, \& Shoffner (1981) and Feng, et al., (1991) describe their rational of amphibian or basilar papillae tuning based solely on high or low frequency BEF populations. Schmitz, et al., (1992) based their end organ innervation on the previously described results from Mudry, et al., (1977), Megela, \& Capranica, (1981), and Feng, et al., (1991). Similarly, Ronken (1990) based BP fiber origin on results from Megela \& Capranica (1981). The end organ innervation assumptions of Schmitz, et al., (1992) and Ronken (1990) are 


\section{METHODS}

\section{Subjects}

21 adult Rana pipiens (leopard frogs) were randomly purchased from a commercial supplier. All animals were given liberal access to water and fed five crickets per week.

\section{Animal preparation}

Surgery was conducted under a dissecting microscope and consisted of exposure of the cranium and implantation of three wire electrodes to be used for near field BSER recordings. Each frog was anesthetized by immersion for $10-15 \mathrm{~min}$ in a solution of 3 $\mathrm{mM}$ Tricaine methanosulfonate buffered with bicarbonate, or until the eye-blink reflex was suppressed. The frog was then placed on a bed of ice to slow its blood flow during surgery. Three holes were drilled in the exposed cranium. Two $1.0 \mathrm{~mm}$ diameter holes were drilled for the active and recording electrodes above the diencephalon $(3 \mathrm{~mm}$ caudal and $1 \mathrm{~mm}$ dorsal lateral to the eye midline) and a third hole for the ground electrode $2 \mathrm{~mm}$ dorso-rostral to the eye midline. Each electrode consisted of a $40 \mathrm{~mm}$ length of seven stranded stainless steal wire coated with teflon $(0.5 \mathrm{~mm}$ bare diameter, $39 \mathrm{~mm}$ coated diameter; A-M Systems, 7935). All electrodes were fixed to the cranium with cyanoacrylic adhesive, and covered with dental cement. 


\section{$\underline{\text { Stimulation }}$}

The stimulus presentation and response recording occured in an ACI ANSI 1991 calibrated sound treated test chamber. The recording arena within the sound chamber consisted of plywood $(81 \times 80 \times 71 \mathrm{~cm})$ bordered by $10 \mathrm{~cm}$ of fiberglass insulation material on the walls to reduce acoustic reverberation. The floor of the arena was $73 \mathrm{~cm}$ above the chamber floor, and lined with acoustic dampening material. Figure 1 is the schematic diagram of the instrumentation to be used.
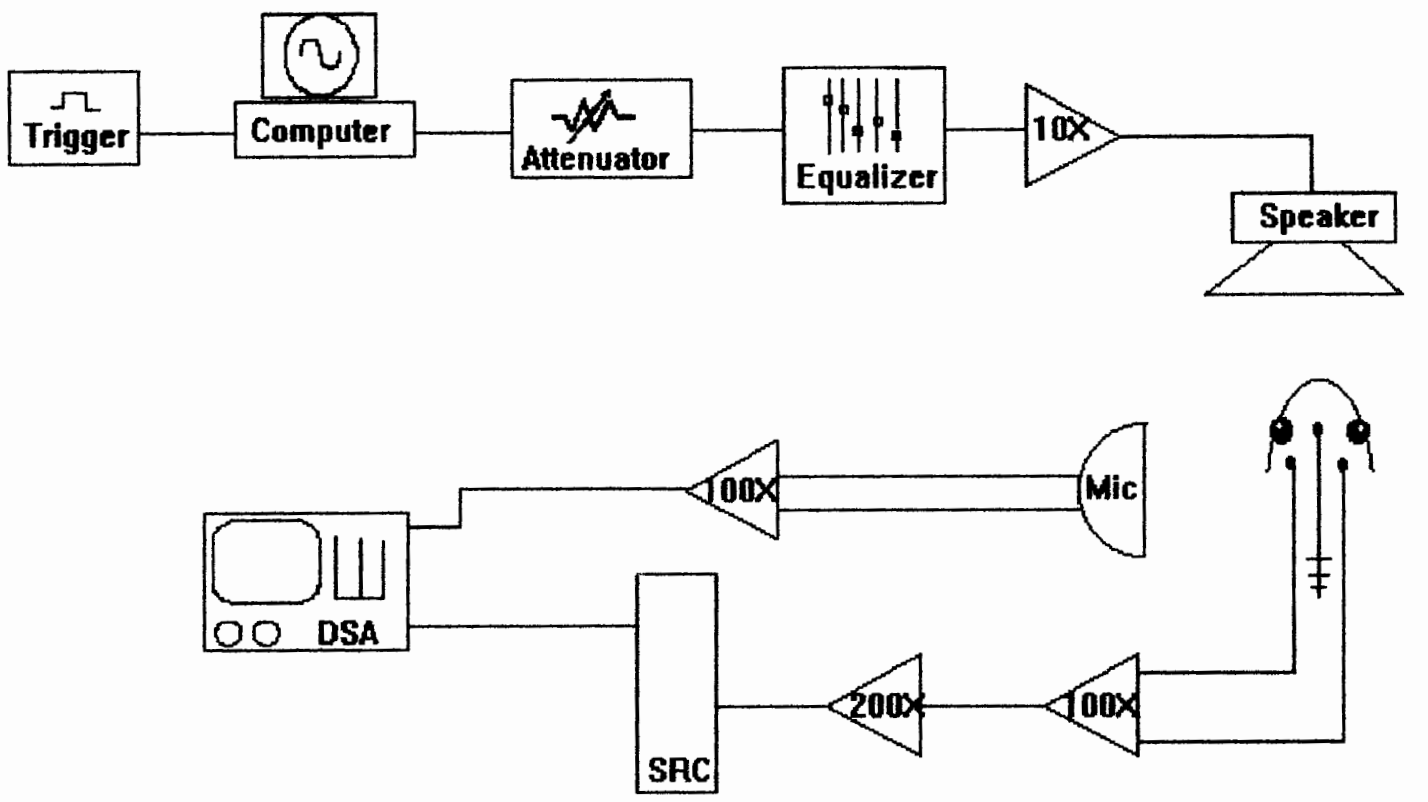

Figure 1. Stimulation and recording instrumentation. 
The signals used for threshold testing were computer generated (Macintosh II CI; GW Instruments) narrow band clicks (rise-fall-time $1 \mathrm{~ms}, 3 \mathrm{~ms}$ plateau) with bandwidths corresponding to either AP or BP frequency ranges (Figure 2). Stimulus rate was controlled by a Krohn-Hite Model 2100 clock generator set to $11 / \mathrm{sec}$. Stimulus level was controlled manually by a Hewitt Packard 350 step-attenuator.

The computer-generated signals was amplified 10 times by a Hafler P230 Amplifier to drive one of three speakers. A Rane FPE 13 Parametric Equalizer was used to flatten the frequency response of the speakers. The loudspeaker used for threshold acquisition was a Realistic Minimus 3.5 speaker suspended $1 \mathrm{~m}$ above the recording arena. A Celestion Power Unit RTT 50X Ring Tweeter was used to transduce the BP narrow band noise. The AP noise was transduced by a low frequency driver.

A $14 \times 17 \times 12 \mathrm{~cm}$ copper screen cage was placed in the recording arena in which the frog will be free to move during testing. Sound levels at the frog's tympanum were monitored by means of a $1 / 2$ inch ACO Pacific 7200 microphone and a PS9200 preamplifier (100 times). Output of the preamplifier was band-pass filtered (Krohn-Hite 3700) and viewed on the digital oscilloscope (Tekniques DSA 610A). A Bruel \& Kjaer 2203 sound level meter with an ACO Pacific 7200 1/2 inch microphone was used to determine sound pressure levels of the signals.

\section{Response Recording}

Output of the active electrode was inverted and the signal amplified 100 times 


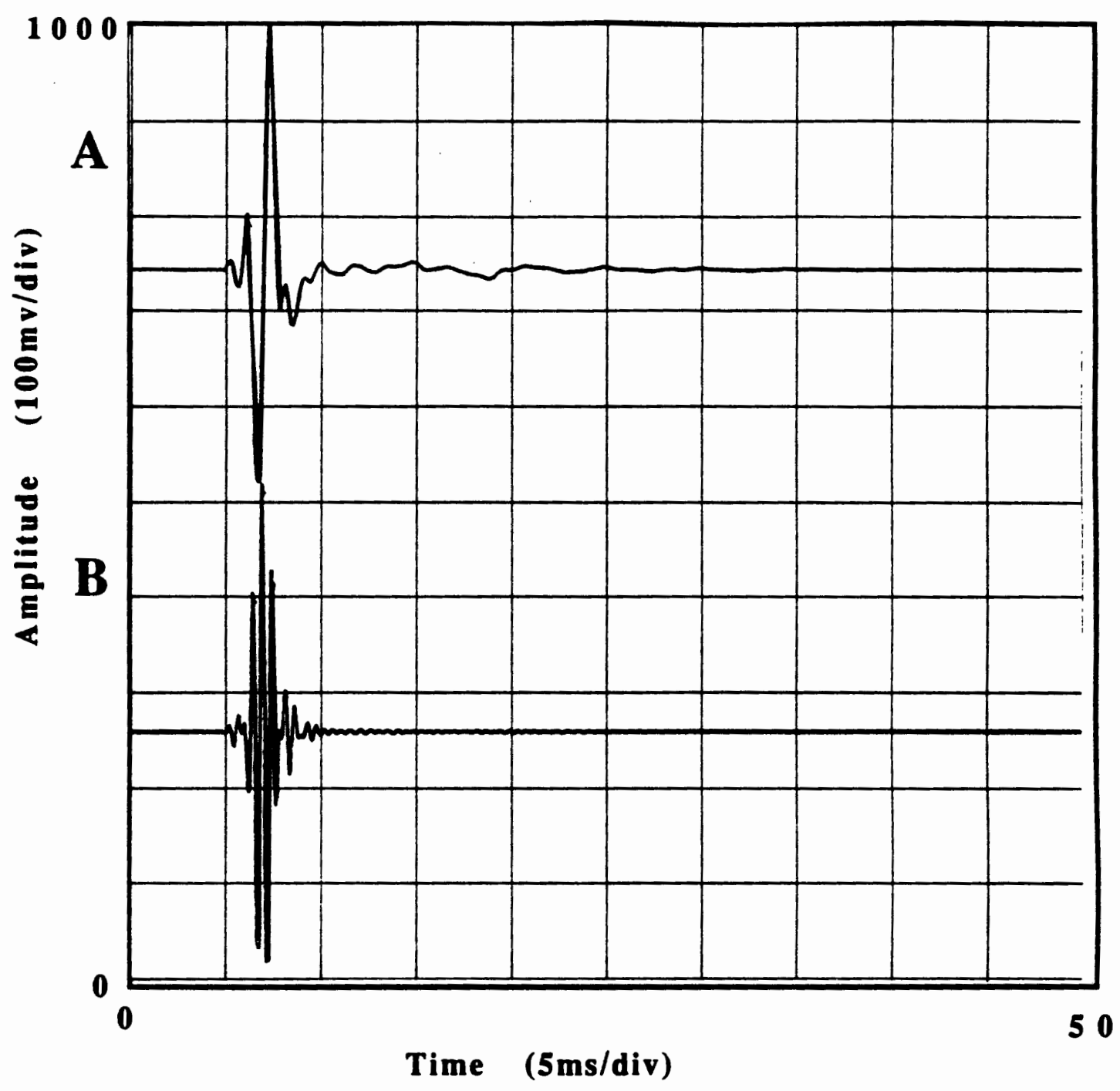

Figure 2. AP (2A) and BP (2B) acoustic stimuli recorded at $40 \mathrm{~dB}$ SPL $1 \mathrm{~m}$ from loudspeaker (see methods). 
by a WPI DAM 80 differential amplifier with a recording bandwidth of $1 \mathrm{~Hz}-3 \mathrm{~K} \mathrm{~Hz}$. Output of the differential amplifier was further amplified 200 times with a Tek Amps 26 A2. The responses was then run through a signal reject circuit developed by our laboratory that eliminated large electrical artifacts generated from the frog due to movement. The responses were averaged using 512 sweeps and stored for analysis using a Tek DSA601A 14 bit equivalent amplitude precision digital oscilloscope. Brain signal average onset was triggered by stimulus onset. 


\section{PROCEDURE}

\section{AP \& BP Threshold Acquisition}

BSER waveforms were recorded in response to both AP and BP computer generated narrow band click stimuli. Averaged BSER waveforms were displayed on the DSA oscilloscope for on-line analysis and stored on disk for later analysis. Threshold acquisition was as follows. First, wave III of the BSER waveform was identified for 80 $\mathrm{dB}$ SPL and $70 \mathrm{~dB}$ SPL click presentations. Next, wave III threshold was determined by presenting clicks at $5 \mathrm{~dB}$ decrements until the disappearance of wave III. Clicks were

then presented at $1 \mathrm{~dB}$ increments until reappearance of wave III. Threshold was defined as the lowest SPL at which wave III is apparent.

It took approximately 1.5 minutes to average 512 sweeps at a given click stimulus presentation. Thresholds were determined one week after surgery for each animal and prior to noise exposure. If post-surgery and pre-noise exposure thresholds differed by more than five $\mathrm{dB}$, threshold acquisition continued until a stable threshold was obtained from each click stimulus.

\section{Fatiguing Procedure}

Frogs were randomly divided into four groups based on the bandwidth of the fatiguer (Figure 3, Table 2). Baseline thresholds of each animal was determined using the $\mathrm{AP}$ and $\mathrm{BP}$ clicks prior to fatiguer presentation. Each fatiguer was presented for 10 minutes at $103 \mathrm{~dB}$ SPL. Threshold determination began approximately 1.5-3 minutes after fatiguer offset. Because it took approximately 1.5 minutes to average 512 sweeps 


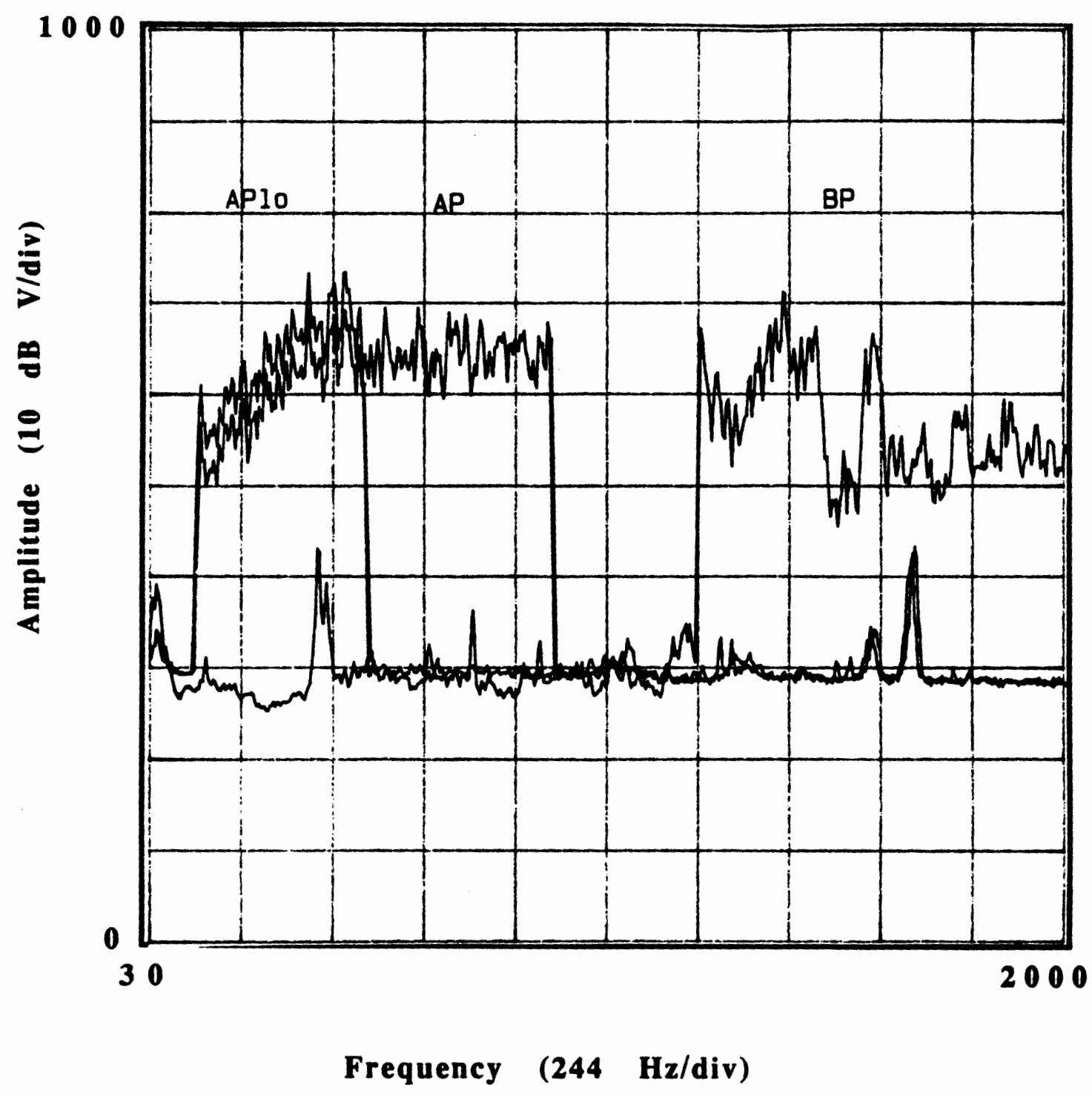

Figure 3. FFT of the APlo, AP, and BP fatiguers recorded at $103 \mathrm{~dB}$ SPL $1 \mathrm{~m}$ from loudspeaker (see methods). 
at a given click stimulus presentation, this time was the earliest possible threshold measurement time. However, threshold rapidly recovers within the first two minutes after exposure, so it is possible that the true threshold may decrease past the click presentation level within this 1.5 minute averaging time. Therefore it may take up to eight minutes post fatiguing stimulus time to obtain a true threshold. This does not imply that thresholds recorded within the first eight minutes are invalid; only that it may take longer to record initial thresholds in a particular experiment. Thresholds were measured in approximately two minute intervals for the first ten minutes, and then measured in approximately five minute intervals until initial threshold SPL had been attained.

Table 2. Experimental Groups

\begin{tabular}{|l|l|}
\hline GROUP & FATIGUER BANDWIDTH \\
\hline Ap low & $150-600 \mathrm{~Hz}$ \\
\hline AP & $150-1100 \mathrm{~Hz}$ \\
\hline BP & $1300-3000 \mathrm{~Hz}$ \\
\hline AP+curare & $150-3000 \mathrm{~Hz}$ \\
\hline AP+saline & $150-1100 \mathrm{~Hz}$ \\
\hline
\end{tabular}

Two groups of frogs were exposed to fatiguing noises within the AP frequency ranges. The "AP group" were exposed to a $150-1100 \mathrm{~Hz}$ narrow-band noise, which presumably corresponds to frequencies at which the majority of AP fibers are tuned. The "AP low" group was exposed to a $150-600 \mathrm{~Hz}$ narrow-band fatiguing noise. This group was included to investigate the organ-specific effect of the low frequency AP fiber 
population. The "BP group" was exposed to a $1300-3000 \mathrm{~Hz}$ narrow-band noise, which presumably corresponds to possible frequency ranges to which BP fibers may be tuned. To ensure that middle ear muscle contraction was not affecting results, d-tubocurarine chloride was used to paralyze the middle ear muscles of the "AP+curarine" group. This group was exposed to the AP fatiguer, but was also subjected to intermuscular injection of curarine $(0.004 \mathrm{mg} / \mathrm{g}$ body weight, $1 \mathrm{M}$ injection) prior to fatiguer presentation. Finally, an "AP+saline group" consisted of animals exposed to the AP fatiguer prior to intermuscular injection of a saline solution ( $1 \mathrm{M} \mathrm{NaCl}$ injection). Post fatiguing thresholds to only the BP click stimuli were recorded for these last two groups.

It was expected that the group exposed to the AP low and AP fatiguers would exhibit threshold shifts measured by the AP click, and would not exhibit a threshold shift measured by the BP click. The BP group was expected to exhibit threshold shifts measured by the BP click, and not the AP click. The null hypothesis is that the AP fatiguer will elicit a threshold shift measured from both AP and BP click stimuli. 


\section{RESULTS}

BSER thresholds to AP and BP clicks were tracked in 21 frogs following exposure to fatiguer. Of the 42 series of threshold measurements, only two did not show shift in threshold after fatiguer presentation. A threshold measurement was obtained at five minutes post fatiguer offset for 36 of the 40 tests in which a shift in threshold was observed. Of the remaining four measurements, no threshold value was recorded at five minutes post fatiguer offset. The time range of threshold measurement in these four frogs was 3-6 minutes post-fatiguer offset. Therefore, 3-6 minute post-fatiguer offset was chosen as the value of initial threshold shift measurement. In each group, threshold recovery was measured as the time at which post-fatiguer threshold equalled pre-fatiguer threshold.

Threshold recoveries from the "AP Group" are shown in Figure 4. All animals in this group $(\mathrm{N}=5)$ were exposed to a $150-1100 \mathrm{~Hz}$ narrow-band noise presented at 103 $\mathrm{dB}$ SPL for 10 minutes. Thresholds measured in response to the AP click exhibited a mean shift of $14 \mathrm{~dB}(\mathrm{~s} . \mathrm{d} .=2 \mathrm{~dB})$. Mean threshold recovery time in response to the AP click was $36 \min (s . d .=3 \mathrm{~min})$. Thresholds measured in response to the BP click exhibited a mean shift of $6 \mathrm{~dB}(\mathrm{~s} . \mathrm{d} .=2 \mathrm{~dB})$, and a mean threshold recovery time of 27 $\min (\mathrm{s} . \mathrm{d} .=14 \mathrm{~min})$

Figure 5 shows thresholds measured from the "AP low Group". Animals in this group $(\mathrm{N}=5)$ were exposed to a $150-600 \mathrm{~Hz}$ narrow-band noise presented at $103 \mathrm{~dB} \mathrm{SPL}$ for 10 minutes. Thresholds measured in response to the AP click exhibited a mean threshold shift of $12 \mathrm{~dB}(\mathrm{~s} . \mathrm{d} .=3 \mathrm{~dB}$ ) and a mean threshold recovery time of $39 \mathrm{~min}$ (s.d.= 


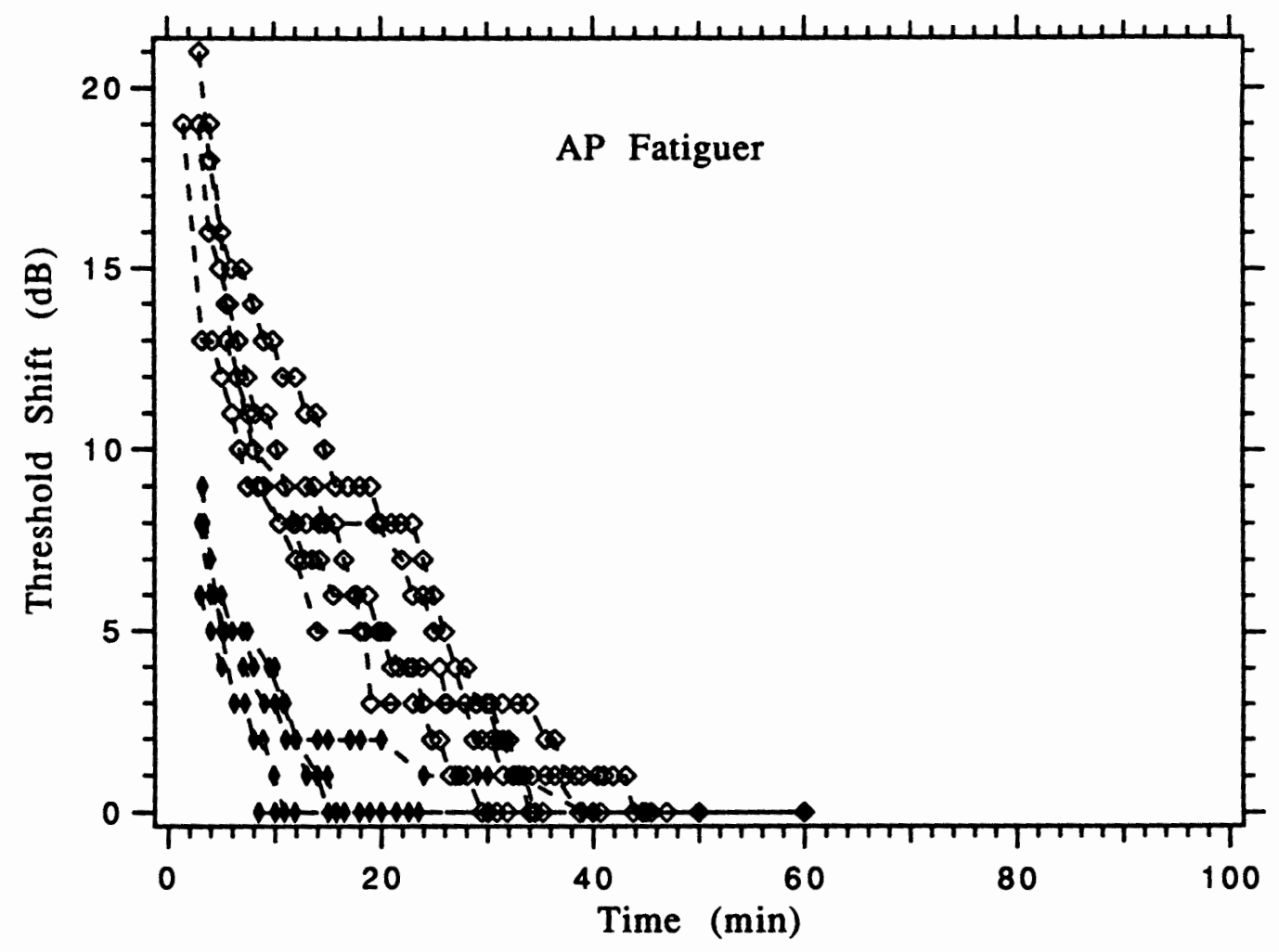

Figure 4. AP, BP recovery following AP noise exposure. Filled symbols=BP thresholds, un-filled symbols=AP thresholds. AP \& BP thresholds measured with AP and BP click stimuli, respectively ( $N=5$; see methods). 


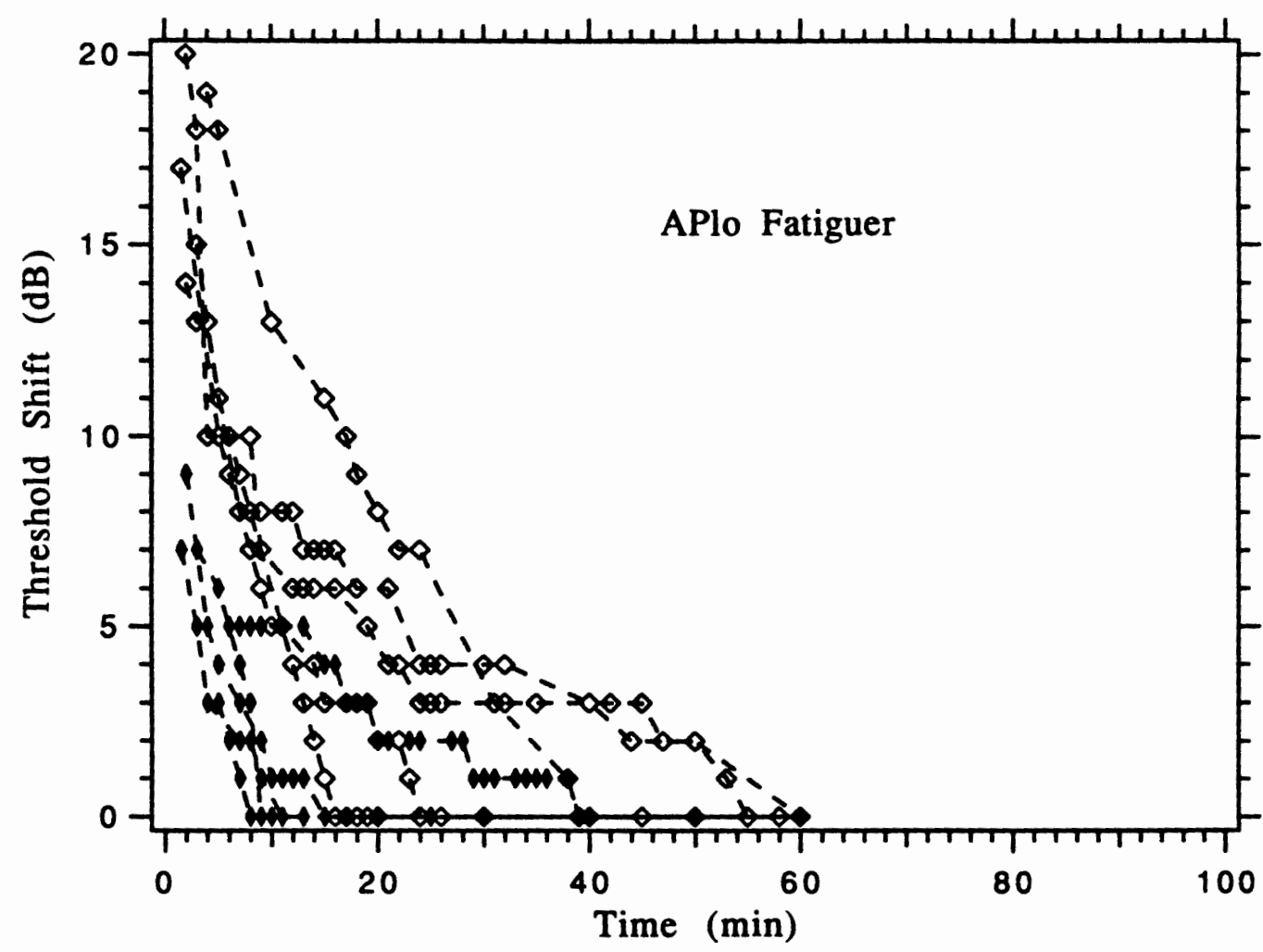

Figure 5. AP, BP recovery following APlo noise exposure. Filled symbols=BP thresholds, un-filled symbols=AP thresholds. AP \& BP thresholds measured with AP and BP click stimuli, respectively ( $\mathrm{N}=5$; see methods). 
$19 \mathrm{~min}$ ). Thresholds measured in response to the BP click exhibited a mean threshold shift of $4 \mathrm{~dB}(\mathrm{~s} . \mathrm{d} .=1 \mathrm{~dB})$, and a mean threshold recovery time in response to the BP click of $15 \mathrm{~min}(\mathrm{~s} . \mathrm{d} .=13 \mathrm{~min})$.

Figure 6 shows thresholds measured from animals exposed to a $1300-3000 \mathrm{~Hz}$ narrow-band noise presented at $103 \mathrm{~dB}$ SPL for 10 minutes $(\mathrm{N}=6)$. This narrow-band noise was intended to fatigue the basilar papilla. Thresholds measured in response to the AP click exhibited a mean threshold shift of $9 \mathrm{~dB}(\mathrm{~s} . \mathrm{d} .=7 \mathrm{~dB})$ and a mean threshold recovery time of $33 \mathrm{~min}(\mathrm{s.d} .=35 \mathrm{~min})$. Thresholds measured in response to the BP click exhibited a mean threshold shift of $8 \mathrm{~dB}(\mathrm{~s} . \mathrm{d} .=3 \mathrm{~dB})$, and a mean threshold recovery time in response to the BP click of $40 \mathrm{~min}(\mathrm{~s} . \mathrm{d} .=23 \mathrm{~min})$.

Figure 7 shows thresholds measured from the "AP+curare Group". Animals in this group $(\mathrm{N}=5)$ were exposed to the AP fatiguer $(150-1100 \mathrm{~Hz}$ narrow-band noise) presented at $103 \mathrm{~dB}$ SPL for 10 minutes. Thresholds measured from animals injected with curare exhibited a mean threshold shift of $10 \mathrm{~dB}(\mathrm{s.d} .=2 \mathrm{~dB})$ and a mean threshold recovery time of $45 \mathrm{~min}(\mathrm{~s} . \mathrm{d} .=16 \mathrm{~min})$. Thresholds measured from animals injected with saline exhibited a mean threshold shift of $8 \mathrm{~dB}(\mathrm{~s} . \mathrm{d} .=2 \mathrm{~dB})$, and a mean threshold recovery time of $41 \mathrm{~min}(\mathrm{s.d} .=13 \mathrm{~min})$.

\section{Statistical Analysis}

The data were subjected to a Multivariant Analysis of Variance (MANOVA) with two dependant variables (threshold shift and recovery time) and two independant variables (fatiguer type and stimulus type). Table 3 summarizes these results. There was 


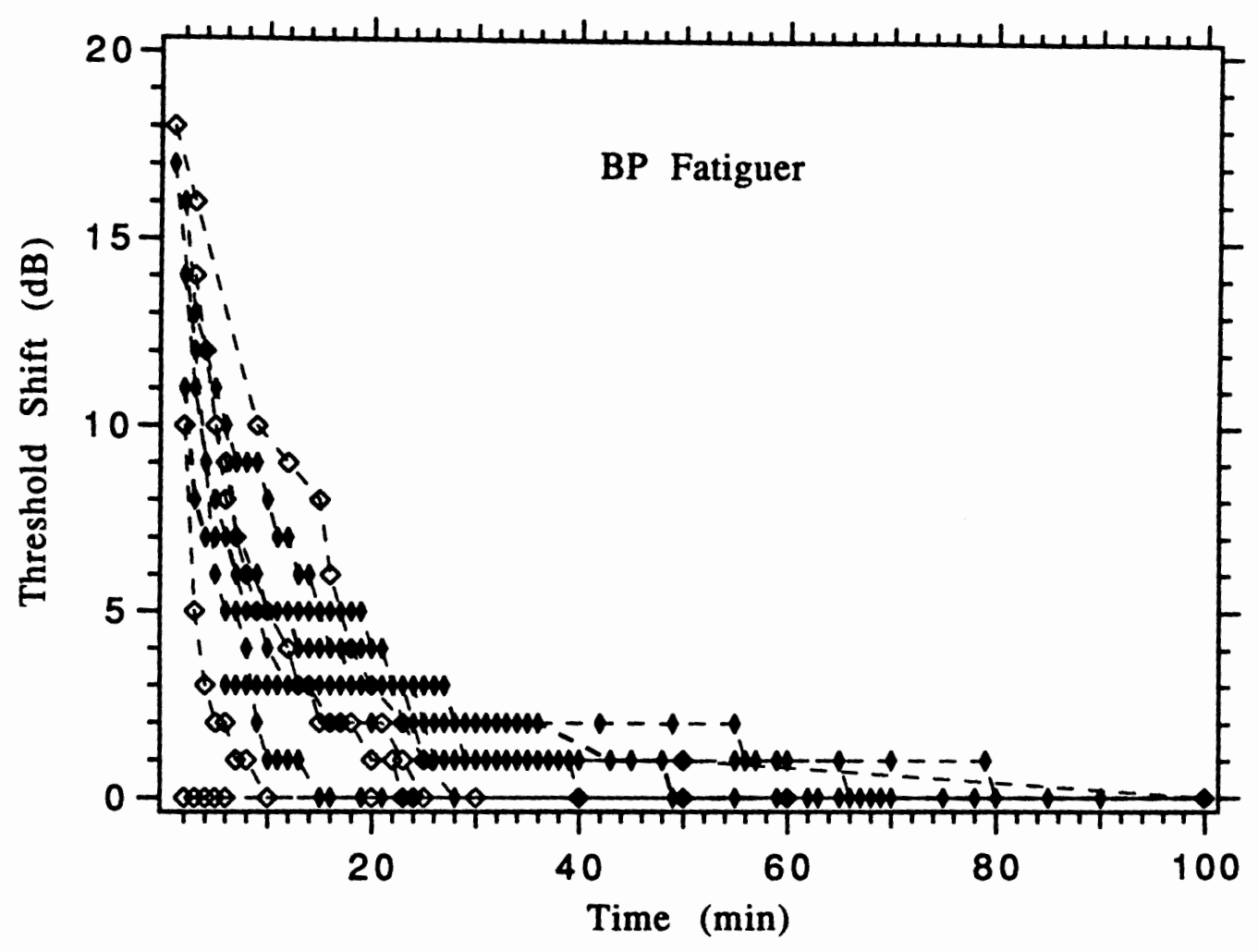

Figure 6. AP, BP recovery following BP noise exposure. Filled symbols=BP thresholds, un-filled symbols $=A P$ thresholds. AP \& BP thresholds measured with $A P$ and BP click stimuli, respectively $(\mathbb{N}=6$; see methods). 


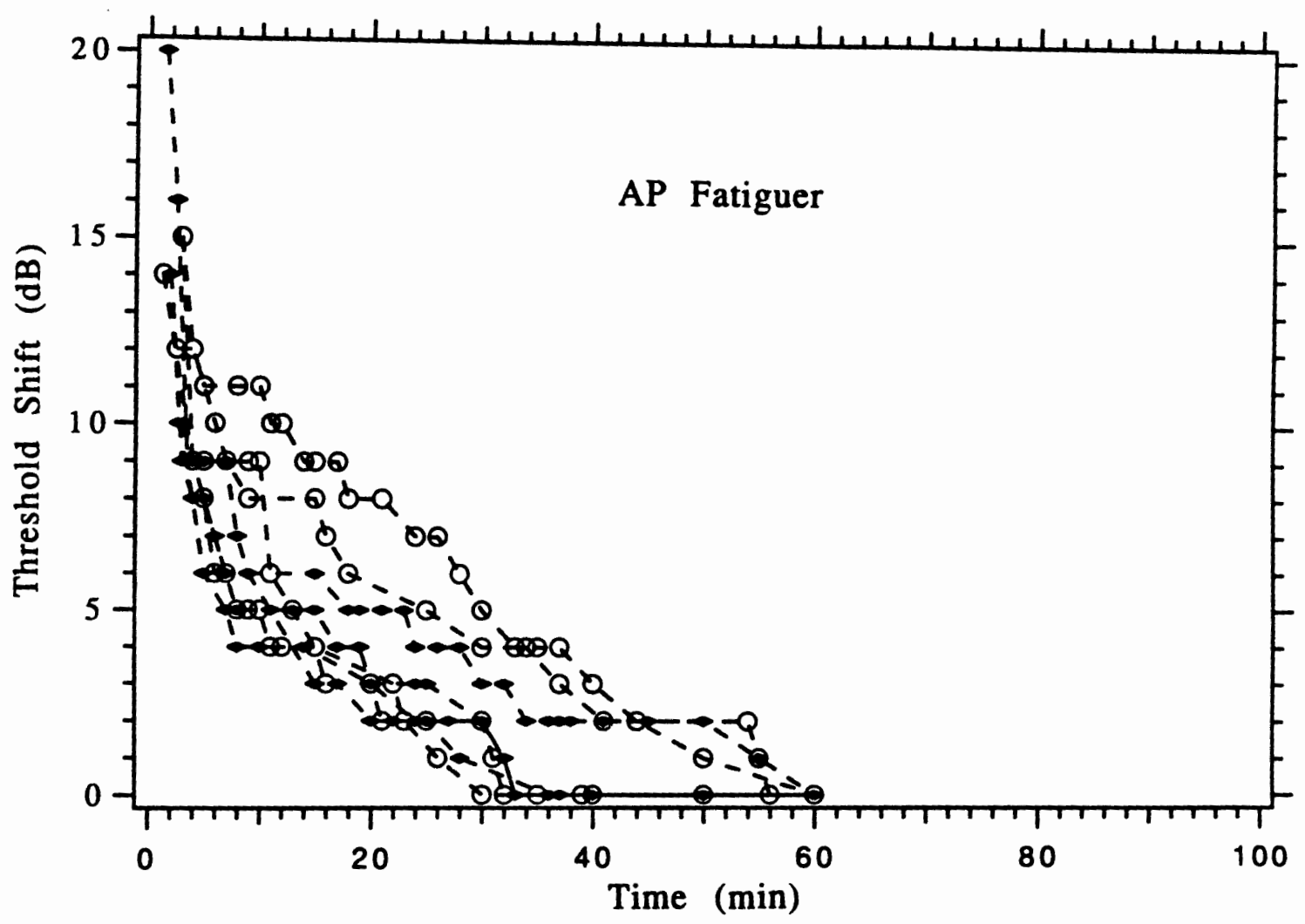

Figure 7. BP recovery following AP noise exposure. Filled symbols=BP+saline thresholds, un-filled symbols $=B P+$ curare thresholds. BP thresholds measured with BP click stimuli (see methods). 
no significant main effect of fatiguer type for either threshold shift $(p<0.891)$ or recovery time $(p<0.321)$. However, there was a significant main effect for threshold shift magnitude $(p<0.000)$, and a significant interaction of fatiguer type by click type ( $p<$ 0.038). No such differences were observed in recovery time.

\section{Table 3. Results of MANOVA}

\begin{tabular}{||l|l|l|l|l|}
\hline DV $=$ Threshold Shift & DF & F & p \\
\hline Group (3 levels) & 3.47 & 2 & 1.73 & .891 \\
\hline Method (2 levels) & 338.96 & 1 & 25.94 & .000 \\
\hline Interactions & SS & DF & F & $p$ \\
\hline Group X Methods & 111.39 & 2 & 4.26 & .038 \\
\hline DV= Recovery Time & & & & \\
\hline Main Effects & SS & DF & F & p \\
\hline Group (3 levels) & 739.93 & 2 & 1.24 & .321 \\
\hline Method (2 levels) & 1207.94 & 1 & 1.94 & .187 \\
\hline Interactions & SS & DF & F & p \\
\hline Group X Methods & 1584.08 & 2 & 1.27 & .313 \\
\hline
\end{tabular}

\section{Within Group Difference}

Table 4 summarizes the results of the non-parametric Mann-Whitney U-test. The AP fatiguer produced both significantly greater AP threshold shifts $(p<0.012)$ and AP threshold recovery time $(p<.037)$ than BP threshold shifts and recovery. The AP low fatiguer produced a significantly greater AP threshold shift than BP threshold shift $(p<0.012)$, and a significantly greater AP recovery time $(p<0.037)$. There was no significant difference between AP and BP threshold shifts ( $p<0.687$ ) or between AP and 
BP recovery time $(p<0.298)$ in the BP fatiguer group. There was no significant differences in BP threshold shift $(p<0.391)$ or in BP recovery time $(p<0.144)$ between animals injected with curare verses animals injected with saline.

Table 4. Results of Mann-Whitney U-test

\begin{tabular}{|l|l|l|}
\hline Group & Threshold Shift $(\mathrm{p})$ & Threshold Recovery $(\mathrm{p})$ \\
\hline AP & 0.012 & 0.037 \\
\hline AP low & 0.012 & 0.037 \\
\hline BP & 0.687 & 0.298 \\
\hline $\begin{array}{l}\text { AP+ curare X } \\
\text { AP + saline }\end{array}$ & 0.391 & 0.144 \\
\hline
\end{tabular}

\section{Between Group Difference}

Two Kruskal-Wallis non-parametric One-way ANOVAs were conducted to examine the between group difference of either AP and BP click threshold shift and recovery (Table 5). The first one-way ANOVA examined AP click threshold responces across three groups of fatiguer types. There was neither a significant difference between the magnitude of AP threshold shift nor in recovery time between the AP, AP low, and BP groups. The second one-way ANOVA examined BP click responces across five groups (AP, AP low, $\mathrm{BP}, \mathrm{AP}+$ curare, and $\mathrm{AP}+$ saline). There was a significantly greater magnitude of BP threshold shift and recovery time between these five groups.

Table 5. Results of One-way ANOVA 


\begin{tabular}{|l|l|l|}
\hline $\begin{array}{l}\text { Responses from } \\
\text { Click stimulus }\end{array}$ & Threshold Shift X Group (p) & $\begin{array}{l}\text { Threshold Recovery X } \\
\text { Group (p) }\end{array}$ \\
\hline AP & 0.254 & 0.428 \\
\hline BP & 0.004 & 0.039 \\
\hline
\end{tabular}

Table 6 shows the results of the Tukey-HSD Pair-wise Comparison of the between group difference in threshold shift magnitude and threshold recovery time for the BP click responces. A significantly greater amount of BP threshold shift occurred between the $\mathrm{BP}, \mathrm{AP}+$ saline, and $\mathrm{AP}+$ curare groups than the $\mathrm{AP}$ and $\mathrm{AP}$ low groups. Additionally, $\mathrm{BP}$ recovery time was significantly longer in the $\mathrm{BP}, \mathrm{AP}+$ saline, and $\mathrm{AP}+$ curare groups than the AP and AP low groups. Therefore, BP threshold shifts are greatest, and BP recovery times are longest, when preceded by the BP fatiguer or when animals are exposed to the AP fatiguer following either curare or saline injection.

Table 6. Results of Tukey-HSD ${ }^{\dagger}$

\begin{tabular}{|l|l|l|l|l|l|}
\hline & $\mathrm{AP}$ & $\mathrm{AP}$ low & $\mathrm{BP}$ & $\mathrm{AP}+$ curare & AP+saline \\
\hline $\mathrm{AP}$ & & & & & \\
\hline $\mathrm{AP}$ low & & & & & \\
\hline $\mathrm{BP}$ & $*$ & $*$ & & & \\
\hline $\mathrm{AP}+$ curare & $*$ & $*$ & & & \\
\hline $\mathrm{AP}+$ saline & $*$ & $*$ & & & \\
\hline
\end{tabular}

${ }^{\dagger}\left({ }^{*}\right)=$ significant difference $(\mathrm{p}<0.05)$ between groups. 


\section{DISCUSSION}

In general, selective organ fatigue as measured by threshold recovery was not obtained in any experimental group. In each experimental group, threshold shift and recovery was measured from the organ that did not contain single units tuned to frequencies within the bandwidth of the fatiguer. Figure 4, for example, indicates that both thresholds elicited by the AP and BP clicks exhibited shifts. If organ-specific stimulation had occurred in this group, it would be expected that the "AP" fatiguing noise with a bandwidth corresponding to the neural tuning of the amphibian papilla (150$1100 \mathrm{~Hz}$ ) would cause an AP click threshold shift without a measurable BP click threshold shift.

Organ-specific fatigue was only observed in two of twenty-one frogs. Thresholds measured in response to the BP click did not shift after fatiguer presentation for one animal in the "AP Group" (Figure 4). However, the first threshold measurement for this animal was not obtained until 8 minutes after fatiguer offset. Therefore, it is unknown if this animal's threshold had shifted and recovered before an accurate threshold measurement was obtained, or if this animal's threshold had shifted at all. Additionally, one frog in the "BP Group" exhibited no shift in AP click threshold 2 minutes after BP fatiguer offset (Figure 6). Since no threshold shifts recorded from these experiments recovered within the first two minutes after fatiguer offset, it is possible that this animal represents the sole example of organ-specific fatigue.

It is possible that organ-specific fatigue was not observed for several reasons. First, the bandwidths of the AP and BP computer generated clicks may have contained 
energy outside of the frequency ranges of their intended end-organs. Figure 8 shows the averaged power spectra of both AP and BP clicks at $40 \mathrm{~dB}$ SPL. The AP click contains some spectral energy as high as $1387 \mathrm{~Hz}$, a frequency at which some authors have found BP single units of Rana pipiens to respond (Feng, \& Shoffner, 1981; Feng, Hall, \& Siddque, 1991, Schmitz, White, \& Narins 1992). Similarly, the BP click contains spectral energy as low as $1190 \mathrm{~Hz}$, which may have stimulated AP fibers (Feng, \& Shoffner, 1981; Feng, Hall, \& Siddque, 1991, Schmitz, White, \& Narins 1992). Therefore, the AP click may have elicited responses from BP units and the BP click may have elicited responses from AP units. However, threshold measurements were obtained at low enough sound pressure levels ( $\sim 40 \mathrm{~dB}$ SPL) that a significant frequency spread of the clicks would be unlikely.

A second possibility is that levels of the fatiguer may have been too high to selectively fatigue either the AP or the BP. Figure 9 shows AP and BP tuning curves of Rana pipiens (Ronken, 1990; Feng, Hall, \& Siddque, 1991). AP tuning curves are typically V-shaped with high $\mathrm{Q}_{10}$ values (Siddque, 1991), while BP tuning curves are Ushape with relatively broad tips and long tails (Megela, \& Capranica, 1981).

Additionally, BP fibers exhibit up to a $50 \mathrm{~dB}$ difference in sensitivity within a given subject (Ronken, 1990). All Fatiguer presentation occurred at 103 dB SPL, which could have been of sufficient intensity to fatigue the tails of fibers in the control papilla. It is possible for this cross-over to manifest as a threshold shift in the collateral papilla.

A third possibility is that the effect might be due to middle or inner ear distortion of the fatiguer. It is possible that fatiguer level was too high for linear energy 


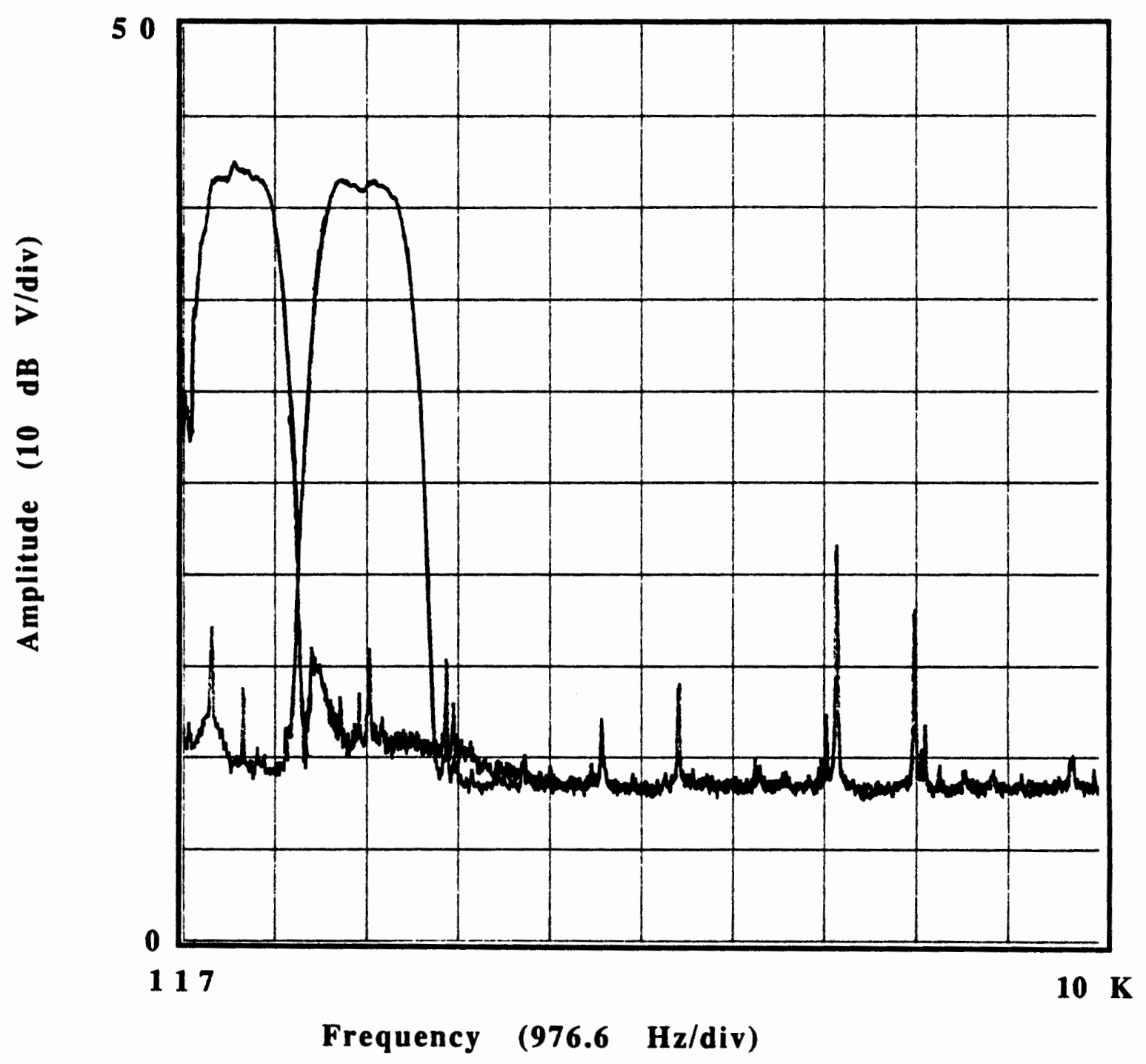

Figure 8. FFT of AP click (left) and BP click (right) recorded at 40 $\mathrm{dB}$ SPL $1 \mathrm{~m}$ from loudspeaker (see Discussion). 


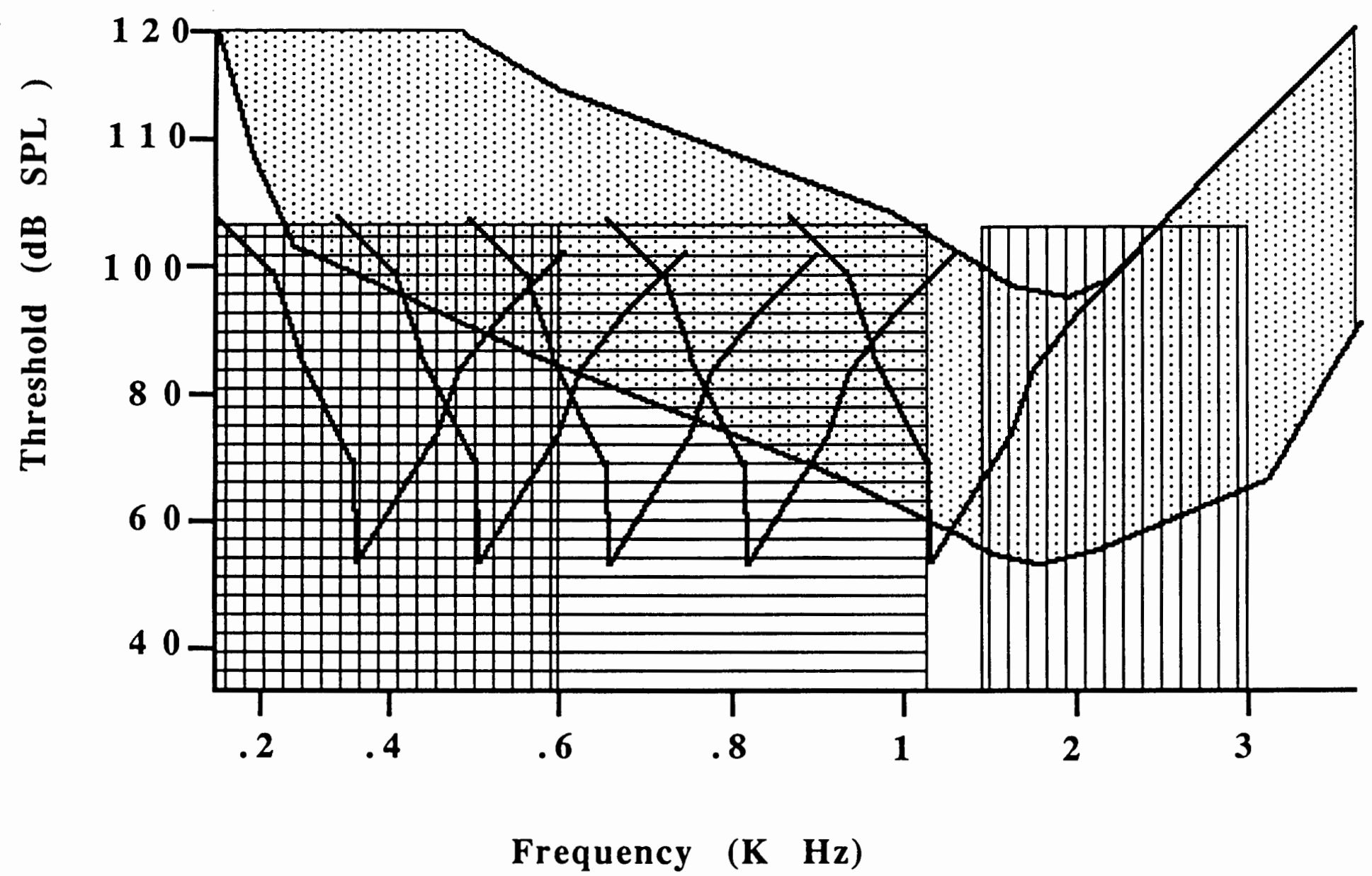

Figure 9. Tuning curve data from Rana pipiens and fatiguer bandwidths. $=\mathrm{AP}$ tuning curves (taken from Feng, Hall, \& Siddque, 1991); tuning curve range (taken from Ronken, 1990); $=$ APlo fatiguer bandwidth; $\square=$ AP fatiguer bandwidth; $\square=$ BP fatiguer bandwidth. 
transfer of the frog's middle ear system. If fatiguer level was too high, the middle ear system may have been driven in such a way as to distort the fatiguer and produce energy in a frequency region other than the intended stimulus. This distortion may have fatigued the collateral papilla and produced the observed collateral threshold shift. Likewise, inner ear hydro-acoustical distortion may have played a role in collateral papilla stimulation. It may be possible that the papillae are hydrodynamically coupled, and stimulation of one papilla may result in stimulation of the other papilla. Hillerdal, et al. (1987) describes intracochlear ischemia in Wilstar albino rats following acoustic trauma. Drescher, et al., (1983) describe the increase in intercochlear concentrations of GABA, asparagine, and glutamate following acoustic overload. Additionally, Bobbin \& Fallon (1992) described that acoustic overload caused a cochlear accumulation of an unidentified amine compound in guinea pigs. If the findings of Hillerdal et al., Drescher et al., and Bobbitt \& Fallon may be extrapolated to assume that these events occur in the anuran inner ear as well, the accumulation of these compounds paired with the decrease of blood circulation to the inner ear may lead to an increase in viscosity of the inner ear fluids. This increase of viscosity may increase inertia of inner ear fluids which may account for the observed colateral stimulation of Rana pipiens.

Thresholds elicited by AP clicks do not differ in either shift magnitude or recovery time regardless of the fatiguer presented. AP thresholds shifted approximately the same amount and recovered roughly within the same time period if preceded by AP, AP low, or BP fatiguers. On the other hand, thresholds elicited from BP clicks exhibited different amounts of shifts depending upon the type of fatiguer presented and whether 
the frog was injected with either saline or curare. BP threshold shifts and recovery times were similar when preceded by the AP or AP low fatiguers. However, BP threshold shifts and recovery times significantly increase when preceded by the BP fatiguer and when animals were exposed to the AP fatiguer following either saline or curare injection.

This suggests that the amphibian papillae is more sensitive to threshold shift than the basilar papilla. Let us assume that maximum energy is introduced to the amphibian papilla when the AP fatiguer is employed and that this energy produces the maximum amount of threshold shift. Further, let us assume that the amphibian papilla receives less energy when exposed to either $\mathrm{BP}$ or $\mathrm{AP}$ low fatiguers. We see no significant difference between threshold shift or recovery time in AP responses regardless of the amount of energy introduced to the amphibian papilla. Therefore, it may be stated that the amphibian papilla responds to a lower level of stimulation by exhibiting a maximum amount of threshold shift. On the contrary, the BP produces maximum threshold shift when preceded by the BP fatiguer. Accordingly, the conclusion may be drawn that the amphibian papilla is more sensitive to acoustic overload than the basilar papilla.

BP threshold shifts are greatest, and BP threshold recovery time is longest, when preceded by the BP fatiguer or when animals are exposed to the AP fatiguer following either saline or curare injection. It may be concluded that an "injection" effect is evident in $\mathrm{BP}$ responses. It may be that the $\mathrm{BP}$ is somehow affected by the injection procedure that results in a maximum BP threshold shift. It is left to be determine whether-or-not AP thresholds likewise exhibit such an effect. 
Zelick \& Narins (1985) describe single unit TTS, adaption and recovery in single units of Eleutherodactylus coqui treefrogs. They found that TTS recovery time was described by either an exponential or double exponential negative function. The data of this experiment, however, fit neither of these models. A possible explanation of the observed deviation from this model may be that the BSER technique used in the present study may be measuring different attributes of the auditory system than Zelick \& Narins. Zelick and Narins recorded single units using pure tone stimuli, therefore they were able to accurately define TTS in single neurons. The present study utilizes narrow-band noise, which presumably fatigues many neurons innervating a particular papilla. Additionally, evidence suggests that more than one papilla was fatigued in the present study. The observation that TTS recovery in the present study does not fit models of single unit TTS recovery may indicate that more than one process is being measured.

Unlike Rana catesbianna, Eleutherodactylus coqui, and other vocal anurans, Rana pipiens do not chorus. This may explain why the AP responses are so sensitive to acoustic overload. It may be that there is no selective advantage for Rana pipiens to have an amphibian papilla tolerant to loud sound levels. The basilar papilla is considered to be the organ tuned to species-specific mate recognition in some species, such as Hyla crucifer (Wilczynski, Zakon, \& Brenowitz, 1984) and Physalaemus pustulous (Ryan, 1980). If the $\mathrm{BP}$ of Rana pipiens is also responsible for species-specific mate recognition, it would make sense that the BP of Rana pipiens would be less sensitive to acoustic overload.

If the BP were easily susceptible to threshold shift, Rana pipiens would be at a 
selective disadvantage in loud environments. However, given that Rana pipiens do not chorus, why would the BP tolerate louder sound levels? Perhaps the answer is that the $\mathrm{BP}$ is the more ancestral of the two papillae. If present non-chorus Rana pipiens have evolved from a population that was once subject to acoustic overload, the BP may be tolerant to louder sound levels because it had once served an evolutionary advantage. 


\section{CONCLUSION}

This study attempted to selectively fatigue and record from either the amphibian or basilar papillae of Rana pipiens. Computer-generated, frequency-specific clicks were used to elicit BSER's from either amphibian or basilar papillae. Narrow-band noise fatiguers were presented in the frequency region of which each papillae are tuned. It was expected that a threshold shift would be elicited in the papillae that received the acoustic trauma, and that no threshold shift would be observed from the collateral papilla.

The results of this experiment indicated that there was no overall difference between the threshold shift of either papilla. Furthermore, the amount of AP threshold shift was relatively constant regardless of whether the fatiguer bandwidth was overloading the amphibian or basilar papillae. By contrast, the amount of BP threshold shift was greater when proceeded by a fatiguer with a bandwidth corresponding to the BP tuning region than by a fatiguer with a bandwidth corresponding to the AP tuning region. Additionally, curare maximized the amount of BP threshold shift following fatiguing noise presented with a bandwidth to which the AP is tuned.

Our findings suggest that further studies are needed to answer some questions of the anuran amphibian and basilar papillae. Will lower fatiguer sound levels prove to be more appropriate for organ-specific stimulation? Are other electrophysioloic techniques, such as the frequency following response, more appropriate than BSER in recording from a single papilla? Does the AP exhibit the same "injection" effect as the observed in the BP? 


\section{References}

Boettcher, F. A., Spongr, V. P., \& Salvi, R. J., (1992). Physiological changes associated with the reduction in threshold shift during interrupted noise exposure. Hearing Research, vol. 62, pp. 217-236.

Bobbin, R. P., \& Fallon, M., (1992). Intense sound increases the level of an unidentified amine found in perilymph. Hearing Research, vol. $\underline{63}$, pp. 157162.

Bricout-Berthout, A., \& Caston, J., (1982). Responses of afferent and efferent neurons to auditory inputs in the vestibular nerve of the frog. Journal of Comparitive Physiology, vol. 147 , pp. 305-312

Brownell, W. E., More, D. K., \& Bertrand. D., (1985). Evoked mechanical responses of isolated cochlear outer hair cells. Science, vol. 227, pp. 194-196.

Canlon, B., Borg, E., \& Flock, A., (1988). Protection against acoustic trauma by preexposure to a low level acoustic stimulus. Hearing Research, vol. $\underline{34}, \mathrm{pp}$. 197-200. 
Capranica R. R., Frishkopf, L. S., \& Nevo, E., (1973). Encoding of geographic dialects in the auditory system of the cricket frog. Science, vol. 182, pp. 12721275.

Carey, M. B., \& Zelick, R., (1992). The effect of sound level, temperature, and dehydration on the ABR in anuran amphibians. Hearing Research, vol. $70, \mathrm{pp}$. 216-228.

Caston, J., \& Gribenski, A., (1979). Interrelations between auditory and vestibular receptors in the frog's labyrinth. Journal of ComparitivePhysiology, vol. 133. pp. 141-149.

Cody, A. R., \& Johnstone. B. M., (1982). Reduced tempoprary and permanent hearing losses with multiple tone exposure. Hearing Research, vol. $\underline{6}$, pp. 291301.

Corwin, J. T., Warchol, M. E., \& Kelly, M. W., (1991). Hair cell development, structure, function, and regeneration. Annual Revue of Neurophysiology, vol.14, pp. 301-333.

Doherty, J. A., \& Gerhardt, H. C., (1984). Acoustic communication in hybrid treefrogs: sound production by males and selective phonotaxis by 
females. Journal of Comparitive Physiology, vol. 154. pp. 319-330.

Dresher, M. J., Dresher, D. G., \& Mendina, J. E., (1983). Effect of sound stimulation at several levels on concentrations of primary amines, including neurotransmitter candidates, in perilymph of guinea pig inner ear. Journal of Neurochemestry, vol. 41 . pp. 309-320.

Feng, A. S., Narins, P. M., \& Capranica, R., R., (1975). Three populations of primary auditory fibers in the bullfrog (Rana catesbeiana): their peripheral orogins and frequency selectivity. Journal of Comparitive Physiology, vol. 100. pp. 221-229.

Feng, A. S., \& Shofner, W., (1981). Peripheral basis of sound localization in anurans. Acoustic properties if the frog's ear. Hearing Research, vol. $\underline{5} . \mathrm{pp}$, 201-216.

Feng, A. S., (1982). Quantitative analysis of intensity-rate and intensity- latency functions in peripheral auditory nerve fibers of northern leopard frogs (Rana pp. pipiens). Hearing Research, vol. 6. pp.241-246.

Feng, A. S., \& Lin., W., (1991). Differential innervation patterns of three divisions of frog auditory midbrain (torus semicircularis). Journal of 
Comparative Neurology, vol. 306. pp. 613-630.

Feng, A. S., Hall, J. C., \& Siddique, S., (1991). Coding of temporal parameters of complex sounds by frog auditory nerve fibers. Journal of Neurophysiology. vol. $\underline{65}$, pp. $424-445$.

Fuzessery, Z. M., \& Feng, A. S., (1983a). Mating call selectivity in the thalamus and midbrain of the lepard frog (Rana pipiens): single unit and multiunit analyses. Journal of Comparitive Physiology, vol. 150. pp. 333-344.

Fuzessery, Z. M., \& Feng, A. S., (1983b). Frequency representation in the doral medullary nucleus of the lepard frog (Rana pipiens). Journal of Comparitive Physiology, vol. 143. pp. 339-347.

Fuzessery, Z. M., \& Feng, A. S., (1983c). Frequency selectivity in the anuran medulla: excitatory and inhibitory tunung properties of single neurons in the dorsal medullary and superior olivary nuclei. Journal of Comparitive Physiology, vol. 150.pp. 107-119.

Hetherington, T. E., Jaslow, A. P., \& Lombaird, R. E., (1986). Comparative morphology of the Amphibian Operculis system: I. General design features and functional interpitation. Journal of Morphology. vol. 190, pp.43- 
61.

Hillerdal, M., Jansson, B., Engstrom, B., \& Borg, E., (1987). Cochlear blood flow in noise-damaged ears.Actademy of Otolaryngology (Stockh), vol. 104, pp. 270278.

Hillery, C. M., \& Narins, P. M., (1984). Neurophysioligical evedence for a traveling wave in the amphibian inner ear. Science, vol. 225. pp. 1037-1039.

Kandel, E. C., (1991). Principles of Neural Science. New York: Elsever.

Khanna, S. M., \& Tonndorf, J., (1968). External and middle ears; the derterminants of auditory threshold curves. Journal of Acoustical Society of America, vol. 61. S4.

Lewis, E. R., Leverenz, E. L., \& Koyama, H., (1982). The tonotopic organization of the bullfrog amphibian papilla, an auditory organ lacking a basilar membrane. Journal of Comparitive Physiology, vol. 145. pp. 437-445.

Lewis, E. R., Baird, R. A., Leverenz, E. L., \& Koyama, H., (1982). Inner ear dye injection reveals peripheral orogins of specific sensativities. Science, ool, 215. pp. 1641-1643. 
Moffat, A. J., \& Capranica, R. R., (1978). Middle ear sensitivity in anurans and reptiles measured by light scattering spectroscopy. Journal of Comparitive Physiology, vol. 127. pp. 97-107.

Mudry, K. M., Constantine-Patton, M., \& Capranica, R. R., (1977). Auditory sensativity of the diencephelon of the leopard frog Rana p. pipiens. Journal of Comparative Physiology, vol. 114, pp. 1-13.

Narins, P. M., Gunther, E., \& Tautz, J., (1988). Accessory pathway for sound transfer in a neotropical frog. Proc. National Academy of Science (USA), vol. 85. pp. 1508-1512.

Patuzzi, R. B.,\& Thompson, M. L., (1991). Cochlear efferent neurons and protection from acoustic trauma: Protection of outer hair cell receptor current and interanimal variability. Hearing Research, vol. 54 , pp. 48-58.

Rajan, R., \& Johnstone, B. M., (1982). Crossed cochlear influences on monaural temporary threshold shifts. Hearing Research, vol. 9, pp. 279-294.

Rajan, R., \& Johnstone, B. M., (1983). Efferent effects elicited by electrical stimulation at the round window of the guinea pig. Hearing Research, yol. 12, pp. 405-417. 
Rajan, R., \& Johnstone, B. M., (1988a). Electrical stimulation of cochlear efferents at the round window reduces auditory desensitization in guinea pigs: I. Dependance on electrical stimulation parameters. Hearing Research, ol. $\underline{36}$, pp.53-74.

Rajan, R., \& Johnstone, B. M., (1988b). Electrical stimulation of cochlear efferents at the round window reduces auditory desensitization in guinea pigs: II. Dependance on level of TTS.. Hearing Research, vol. 36, pp. 75-88.

Rajan, R., \& Johnstone, B. M., (1988c). Binaural acoustic stimulation excersises protective effects at the cochlea that mimic the effects of electrical stimulation of an auditory efferent pathway. Hearing Research, vol. 458, pp. 241-259.

Ronken, D. A., (1990). Basic properties of auditory-nerve responces from a 'simple' ear: the basilar papilla of the frog. Hearing Research, vol. 47. pp. 63-82.

Rossi, M. L., Prigioni, I., Valli, P., \& Casella. C., (1980). Activation of the efferent system in the isolated frog labyrinth: effects on the afferent epsp's and spike discharge recorded from single fibers of the posterior nerve. Brain Research, vol. 185. pp. 125-137.

Ryan, M. J., (1980). Female mate choice in the neotropical frog. Science, vol. 209 , 
pp. 523-525.

Schmitz, B., White, T. D., \& Narins, P. M., (1992). Directionality of phase locking in auditory nerve fibers of the lepard frog Rana pipiens pipiens. Journal of

Comparitive Physiology, vol. 170. pp. 589-604.

Siegel, J. H., \& Kim, D. O., (1982). Efferent neural control of cochlear mechanics? Olivo-cochlear bundle stimulation affects cochlear biochemical non-linearity. Hearing Research, vol. $\underline{6}$, pp. 171-182.

Simmons, A. M., (1990). Masking patterns in the bullfrog (Rana catesbeiana). I:Behavioral effects. Journal of Acoustical Society of America, vol. $\underline{83}$ no. 3 . pp. 1087-1092.

Simmons, A. M., Moss, C. F., \& Daniel, K. M., (1985). Behavioral audiograms of the bullfrog (Rana catesbeiana) and the green tree frog (Hyla cinerea). $\underline{\text { Journal of }}$ Acoustical Society of America vol. 78 no. 4. pp. 1236-1244.

Warr, B., \& Guinan, J. J., (1979). Efferent innervation of the organ of corti: Two separate systems. Brain research. vol. 173, pp. 152-155.

Weaver, E. G., (1973). The ear and hearing in the frog, Rana pipiens. Journal of 
Morphology vol. 141, pp. 461-478.

Weaver, E. G., (1979). Middle ear muscles of the frog. Proc. Natlional Academy of Sciences (USA), vol. 76. p p. 3031-3033.

Weber, M., \& Whitman. R. D., (1990). Efferent gaiting of human auditory attentional processes. International Journal of Neuroscience, vol. 67, pp. 122-134.

Wells, K. D., (1989). Vocal communication in a neotropical treefrog, Hyla ebraccata: responses of males to gradded aggressive calls. Copeia, vol. 2. pp. 461-466.

Wersall, J., Flock, A., \& Lundquist, P., (1965). Structural basis for directional sensitivity in cochlear and vestibular sensory receptors. Hearing Research, vol. 2, pp. 56-77.

White, T. D., Schmitz, B., \& Narins, P. M., (1992). Directional dependance of auditory sensativity and frequency selectivity in the lepard frog. Journal of Acoustical Society of America, vol. 92 no. 4. pp. 1953-1961.

Wilczynski, W., \& Capranica, R., (1983). The auditory system of anuran amphibians. Progress in Neurobiology, vol. 22, pp. 1-39. 
Wilczynski, W., Zakon, H. H., \& Brenowitz, E. A., (1984). Acoustic communication in spring peepers. Journal of Compatative Physiology, yol. 155. pp. 577-584.

Wilczynski, W., McClelland, B. E., \& Rand. A. S., (1993). Acoustic, auditory, and morphological divergence in three species of neotropical treefrog. Journal of Comparitive Physiology, vol. 172. p. 425-438.

Yates, G. K., Cody, A. R., \& Johnstone, B. M., (1983). Recovery of eighth nerve action potential thresholds after exposure to short, intense pure tones: Similarities with temporary threshold shift. Hearing Research, vol. 12, pp. 305-322.

Yu X., Lewis, E. R., \& Feld, D., (1990). Seismic and auditory tuning curves from bullfrog saccular and amphibian papillar neurons. In press, Journal of Comparitive Physiology.

Zakon, H., \& Capranica, R. R., (1981a). Reformation of organized connections in the auditory system after regeneration of the eigth nerve. Science, vol. 213. pp. 242-244.

Zakon, H., \& Capranica, R. R., (1981b). An anatomical and physiological study of regeneration of the eigth nerve in the lepard frog. Brain Research, vol. 209. pp. $325-338$. 